\title{
Under-expression of CK2 3 subunit in cCRCC represents a complementary biomarker of p-STAT3 Ser727 that correlates with patient survival
}

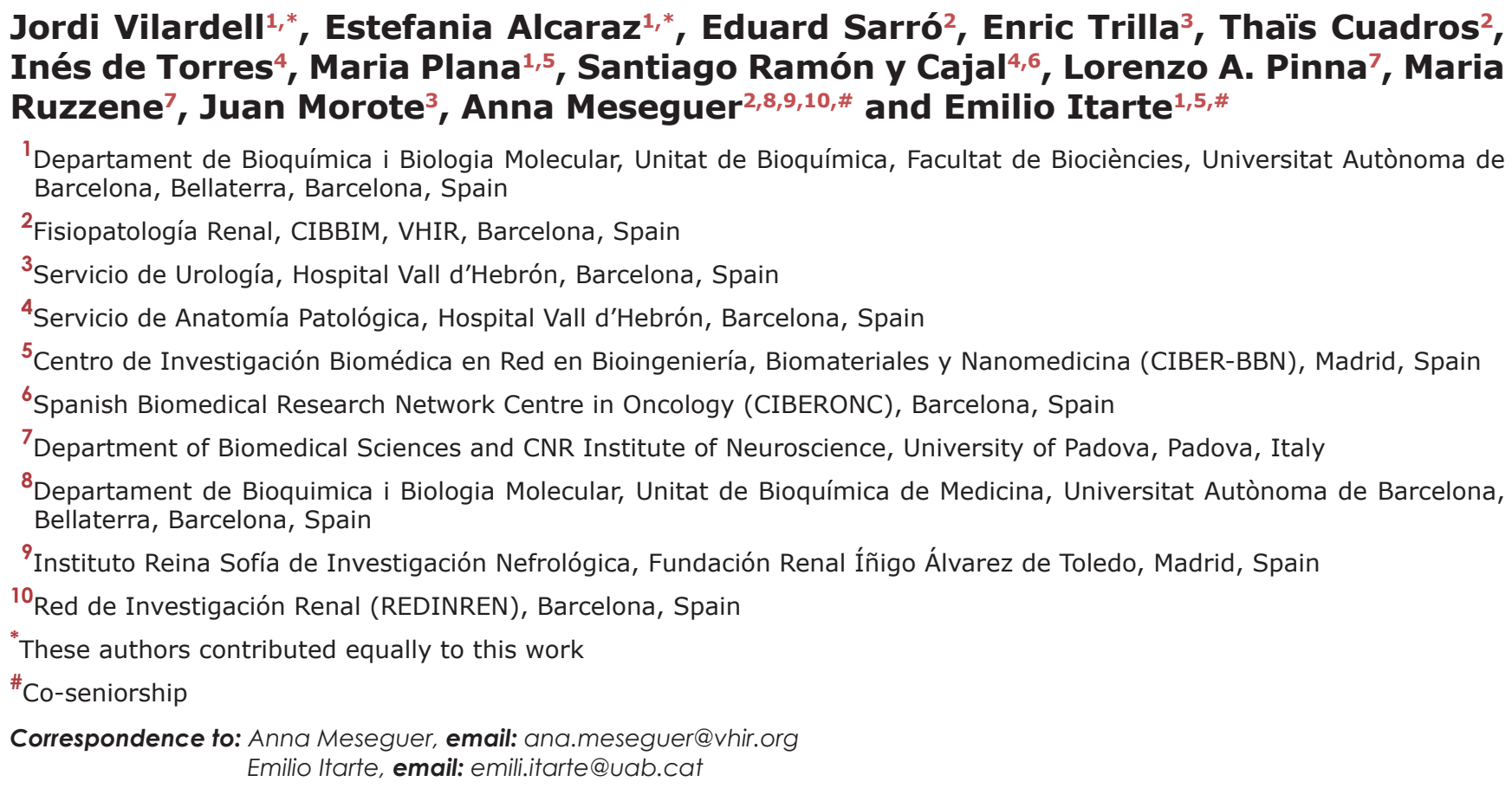

Keywords: protein kinase CK2; clear cell renal cell carcinoma (cCRCC); epithelial-to-mesenchymal transition (EMT); STAT3; patient outcome

Received: March 22, $2017 \quad$ Accepted: December 13,2017 Published: December 19, 2017

Copyright: Vilardell et al. This is an open-access article distributed under the terms of the Creative Commons Attribution License 3.0 (CC BY 3.0), which permits unrestricted use, distribution, and reproduction in any medium, provided the original author and source are credited.

\section{ABSTRACT}

Clear cell renal cell carcinoma (CCRCC) is the most common and aggressive subtype of renal cancer. STAT3 pathway is altered in these tumors and p-STAT3 Ser727 is an independent prognostic factor for CCRCC. Protein kinase CK2 is altered in different types of tumors and overexpression of CK2a is considered predictive of bad prognosis and metastatic risk. CK2 subunits analyses in CCRCC samples showed increased CK2a/a' nuclear content in all cases, but decreased cytosolic CK2 $\beta$ (CK2 2 cyt) levels in the more advanced tumors. Stable downregulation of CK2 $\beta$ in renal proximal tubular (HK-2) and clear cell adenocarcinoma (786-0) cells triggered changes in E-cadherin, vimentin and Snail1 protein levels indicative of epithelial-tomesenchymal transition (EMT), and increased HIF-a. Moreover, CK2 $\beta$ was required in order to observe STAT3 Ser727 phosphorylation in HK-2 but not in 786-0 cells.

We also observed that CK2 $\beta$ improved the prognostic value of p-STAT3 Ser727, as CK2 3 cyt>41 (median value) discriminates patients free of disease for a period of 10 years upon surgery, from those with CK2 3 cyt<41, when p-STAT3 Ser727levels are low.

We conclude that $C K 2 \beta$ down-regulation might represent a mechanism to support EMT and angiogenesis and that CK2 3 cyt levels are instrumental to refine prognosis of CCRCC patients with low p-STAT3 Ser727 levels. 


\section{INTRODUCTION}

Renal cell carcinoma (RCC) is the sixteenth most common cause of death from cancer worldwide and its incidence and mortality rates have been increasing in many countries in the last years $[1,2]$. The clear cell RCC (ccRCC) is the most frequent RCC subtype, comprising $80-90 \%$ of the malignant renal tumors in adults [3]. Originated from renal cells of the proximal convoluted tubule, ccRCC is characterized by the absence of symptomatology until advanced stages of the disease, what is associated with a poor prognosis [4]. ccRCC is highly resistant to radiotherapy and to conventional cytotoxic chemotherapy. Albeit novel targeted therapies have been implemented since 2008, treatment resistance remains a problem for treatment of metastatic patients what makes surgical resection the most common treatment for localized disease [3]. However, approximately onethird of the patients have metastatic disease detected at presentation, and 20 to $30 \%$ of all ccRCC patients undergoing nephrectomy exhibit local or distant disease recurrence during the follow-up. Patients with distant metastases have a poor prognosis and their 5-year survival rate is reduced to around $10 \%$.

Epithelial-to-mesenchymal transition (EMT), a well characterized process in embryogenesis and wound healing, has also been linked to tumor progression and metastasis in a wide number of carcinomas including RCC $[5,6]$. Several signaling pathways, including hypoxia (HIF 1/2) pathway are inducers of the EMT phenotype [7] and it is well known that ccRCCs display deregulation of HIF $1 / 2$ pathway $[8,9]$. The signal transducer and activator of transcription-3 (STAT3) pathway is also deregulated in human RCC [10] and STAT3 has been reported to act as a potent regulator of HIF- $1 \alpha$ and HIF- $2 \alpha$ expression [11] and as a modulator of HIF-1-mediated response [12]. STAT3 activation is reflected through its phosphorylation at Tyr705 and Ser727 residues, both of which are increased in ccRCC tumors. In fact, we have recently shown that p-STAT3 Ser727 is an independent prognostic factor for ccRCC patients [13].

Different reports have shown that protein kinase CK2 is involved in HIF-1 $\alpha$ activation and stabilization [14-16]. Moreover, CK2 activity is necessary for STAT3 activation by IL-6 family cytokines [17] and cell treatment with CK2 inhibitors affect STAT3 phosphorylation on Ser727 $[18,19]$. CK2 is a constitutively active serine/ threonine kinase present in all eukaryotic organisms which acts on a large number of protein substrates involved in a plethora of cellular functions [20]. In mammals, CK2 is composed of two catalytic (CK2 $\alpha$ and CK2 $\left.\alpha^{\prime}\right)$ and a dimer of regulatory subunits $(\mathrm{CK} 2 \beta)$ giving rise to different heterotetrameric forms of the holoenzyme $\left(\alpha_{2} \beta_{2}, \alpha \alpha^{\prime} \beta_{2}\right.$ and $\alpha_{2}^{\prime} \beta_{2}$ ) [21-23]. The CK2 $\alpha$ and CK2 $\alpha$ ' show high similarity in their structural and enzymatic characteristics. Besides its central role in assembling CK2 holoenzyme, CK2 $\beta$ also plays an essential role in the aggregation of CK2 holoenzyme into less active/inactive polymeric assemblies which support an autoinhibitory mechanism of regulation of CK2 [22]. In addition, CK2 $\beta$ helps to discriminate between protein substrates whose phosphorylation is specifically catalyzed by either the free catalytic subunits or CK2 holoenzyme. Interestingly, CK2 holoenzyme is required to phosphorylate snaill what primes its subsequent phosphorylation by GSK3 $\beta$, a process that targets it for degradation [24]. Moreover, downregulation of CK2 $\beta$ was enough to stabilize snaill and to induce an EMT-like phenotype in normal human breast epithelial cells (MCF10A cells) [24].

Increased expression of CK2 catalytic subunits has been shown to occur in different types of human tumors, including renal carcinoma [25-27], and overexpression of both CK $2 \alpha$ and $\mathrm{CK} 2 \alpha^{\prime}$ is considered as predictive of bad prognostic and metastatic risk [27-33]. The information concerning CK2 $\beta$ status in cancer is rather scarce. A preliminary report indicated that in human renal carcinoma the regulatory CK2 $\beta$ subunit increased even in higher amounts than the catalytic CK2 $\alpha$ subunit [25]. In contrast, a recent report using a set of fifteen human renal cell carcinoma cell samples analyzed by western blot detected decreased CK2 $\beta$ levels in some of those samples [26]. However, the correlation between CK2 $\beta$ protein levels and the clinicopathological characteristics of the RCC remains unexplored.

In the present work we aimed to analyze the potential correlation of CK2 subunits with the clinicopathological characteristics of ccRCC tumors and patient survival as well as their impact in HIF expression and STAT3 phosphorylation in human renal cell lines. The results obtained in our work indicate that in ccRCC, CK2 shows not only alterations in the expression of the two catalytic $\left(\mathrm{CK} 2 \alpha^{\prime} / \mathrm{CK} 2 \alpha\right)$ subunits but also in the regulatory CK2 $\beta$ subunit. Moreover, the stable silencing of CK2 $\beta$ in human renal cell lines increases HIF $\alpha$ expression and affects STAT3 phosphorylation. In addition, our results show that cytosolic CK2 $\beta$ levels help to refine the prognostic value of pSer727-STAT3 in ccRCC patients.

\section{RESULTS}

\section{The expression of CK2 subunits shows asymmetric changes in ccRCC tumor progression}

A preliminary analysis by western blot of CK2 subunits in a set of frozen tissue samples from patients with ccRCC showed that they did not follow similar patterns along ccRCC tumor progression (Figure 1, Supplementary Figure 1 and Supplementary Table 1). CK2 $\alpha$ (1AD9 antibody) and CK2 $\alpha$ ' mean values increased in tumor samples of low Fuhrman grade tumors (G1/G2) with respect to normal tissue (set up as fold change of 1) and the 
increases were even more marked in the G3/G4 group. The CK $2 \alpha$ ' values in the G3/G4 tumors were dispersed and the number of tumors too low to reach statistical significance when compared with values observed in G1/G2 tumors. The values shown by the tumors (G1/G2 or G3/G4) were statistically significant respect to values found in normal tissues but they did not reach statistical significance when compared between different tumor groups. On the other hand, CK2 $\beta$ subunit (6D5 antibody) increased in the G1/G2 group but decreased in the more advanced tumors $(\mathrm{G} 3 / \mathrm{G} 4)$. A similar trend was detected when the samples were combined according to their tumor stage in pT1/ pT2 and pT3 groups. Bands detected for CK2 $\alpha$, CK $2 \alpha$ ' and CK2 $\beta$ in the immunoblots of Figure 1 have been also found in the 786-O cell line (Supplementary Figure 1). It is likely that extra bands detected in western blots with

A
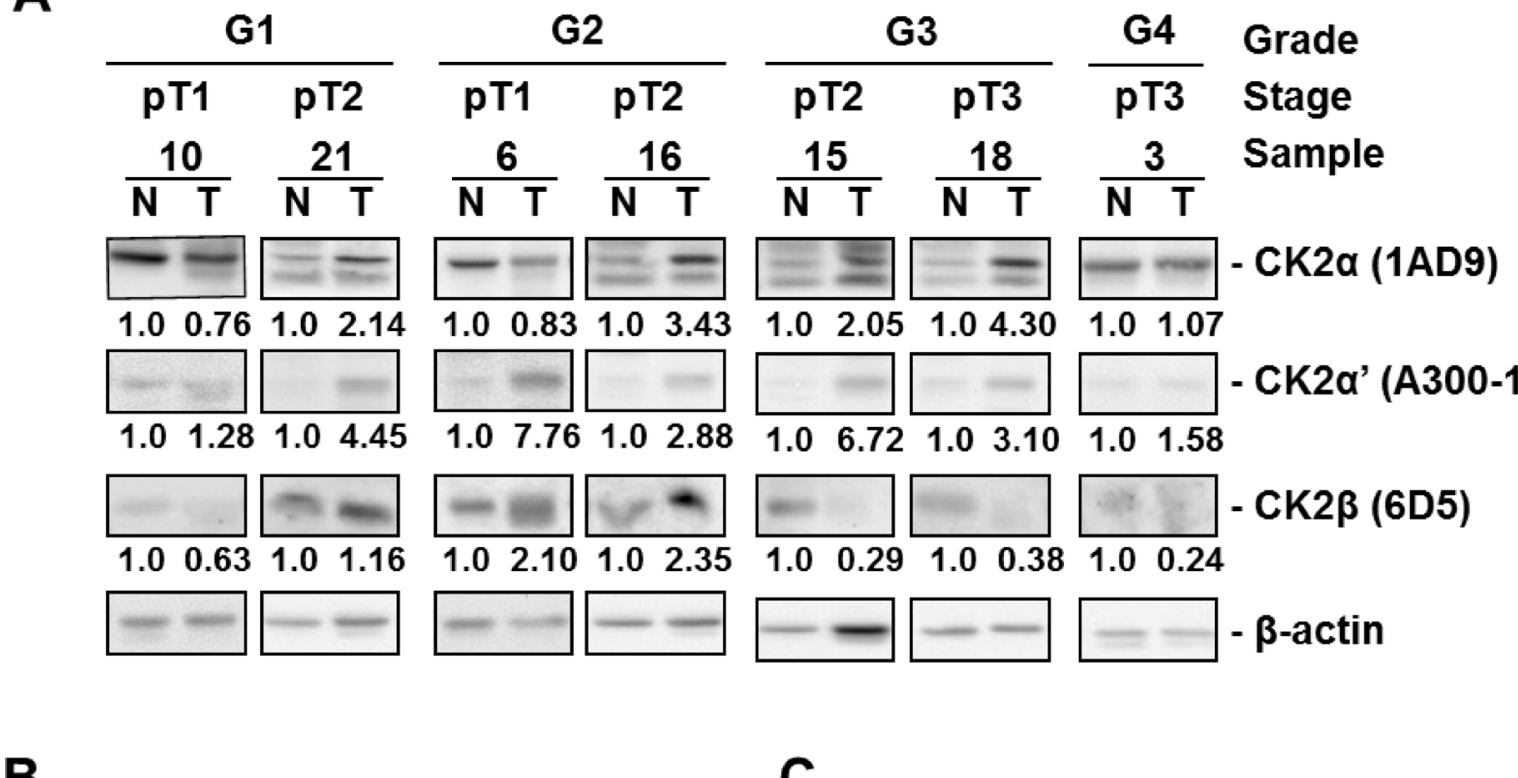

B

\section{C}

CK2 $\alpha^{\prime}(A 300-199 A)$

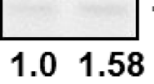

$-C K 2 \beta(6 D 5)$

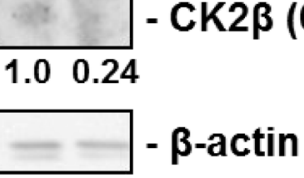

$\square \mathrm{CK} 2 \alpha \square \mathrm{CK} 2 \alpha^{\prime} \square \mathrm{CK} 2 \beta$

$\square \mathrm{CK} 2 \alpha \square \mathrm{CK} 2 \alpha^{\prime} \square \mathrm{CK} 2 \beta$
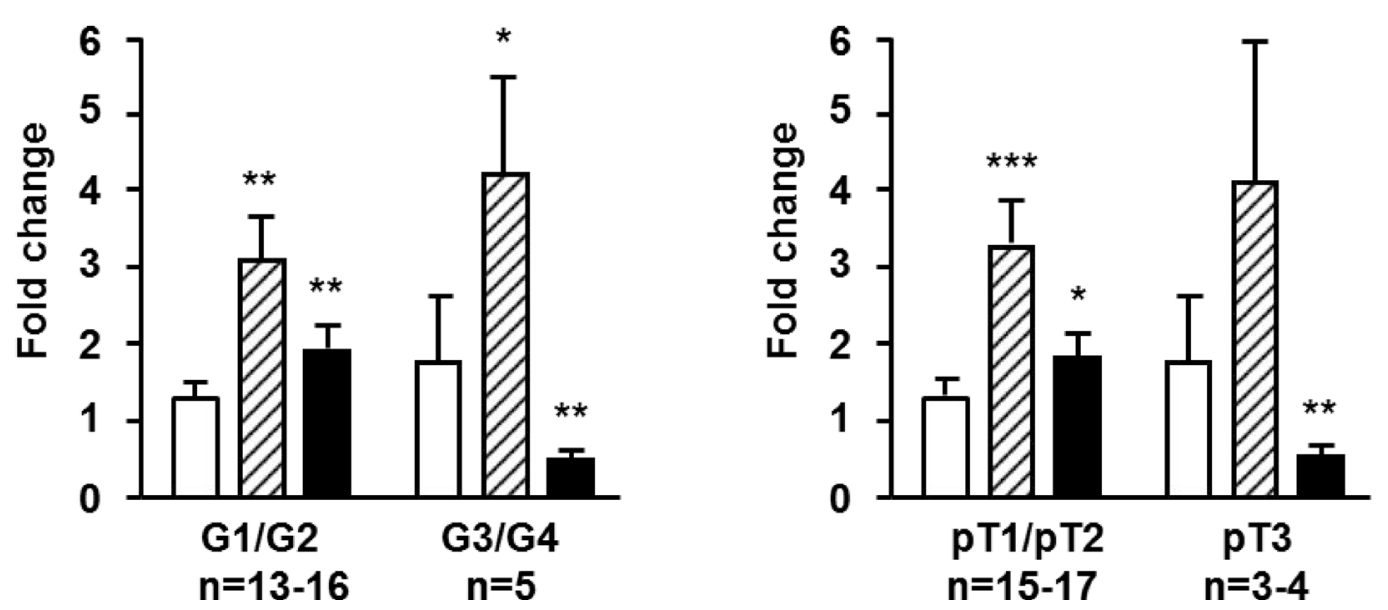

Figure 1: Protein kinase CK2 subunits expression in different extracts of human ccRCC biopsies. (A) Western blot analysis of $\mathrm{CK} 2 \alpha, \mathrm{CK} 2 \alpha^{\prime}, \mathrm{CK} 2 \beta$ and $\beta$-actin expression levels in tissue extracts of representative tumor (T) and unaffected normal (N) kidney counterpart samples from ccRCC patients. The type of antibody used to detect each CK2 subunit is indicated in parenthesis. Samples are classified by their grade (G1 to G4) and tumor stage (pT1 to pT3). (B), (C) Expression ratios of CK2 subunits between tumor and unaffected normal kidney counterpart samples from ccRCC patients, classified by their Fuhrman nuclear grade (B) or their tumor stage (C). Bar graphs show the fold change in CK2 $\alpha, \mathrm{CK} 2 \alpha$ ' and $\mathrm{CK} 2 \beta$ subunit expression in tumors respect to normal kidney counterpart (T/N ratios) after normalization to their $\beta$-actin content. Data are represented as mean +/- SEM. Values were analyzed by Student's $t$-test. $\left({ }^{*}\right),\left(^{* *}\right)$, $\left({ }^{* * *}\right)$ denote $p<0.05, p<0.01$ and $p<0.001$, respectively. Non-significant differences are not indicated. 
the anti-CK2 $\alpha$ (1AD9 antibody) antibody correspond to proteolytic $\mathrm{CK} 2 \alpha$ products.

In order to use a larger number of ccRCC tumor samples, we decided to evaluate $\mathrm{CK} 2 \alpha / \alpha^{\prime}$ and $\mathrm{CK} 2 \beta$ subunits by immunohistochemistry in tissue microarrays (TMA) including tumor and normal counterpart renal tissue samples and the results were correlated with tumor characteristics. The TMA used included 98 ccRCC patients with the following characteristics: $57.1 \%$ men and $42.9 \%$ women, median age: 64 years range: 25 to 86 . Tumor was right side in $59.1 \%$ cases and left in $40.8 \%$ cases. Incidental presentation was found in $52.5 \%$ patients and $46.9 \%$ were symptomatic. $87.9 \%$ presented with localized tumors and $11.1 \%$ with metastasis. $92.9 \%$ patients underwent radical nephrectomy, while 6 underwent nephron-sparing surgery. Median tumor size was $6.4 \mathrm{~cm}$ (range 1.5 to 16). Fuhrman grade was I (G1) in $20.4 \%$, II (G2) in $41.8 \%$, III (G3) in $24.4 \%$ and IV (G4) in $13.2 \%$. The most frequently observed $\mathrm{pT}$ stages were $\mathrm{pT} 1 \mathrm{a}$ in $26.5 \%$ and pT1b in $27.5 \%$. Lympho-vascular invasion was present in only $5.1 \%$ of patients. Finally, UICC risk group was I in $72.4 \%$ and II in $27.5 \%$ of patients studied.

Representative images of ccRCC tumors and unaffected normal kidney counterparts, stained with specific antibodies against $\mathrm{CK} 2 \alpha$ and $\mathrm{CK} 2 \beta$, are shown in Figure 2. The anti-CK $2 \alpha / \alpha^{\prime}(\mathrm{H}-286)$ and anti-CK $2 \beta$ (6D5) antibodies have been used in previous IHC studies $[29,34,35]$. The specificity of the anti-CK2 $\beta$ antibody (6D5) was also assessed by antibody depletion experiments (Supplementary Figure 2). Positive cytosolic and nuclear staining for $\mathrm{CK} 2 \alpha / \alpha$ ' and $\mathrm{CK} 2 \beta$ was detected in renal tubular cells in normal counterpart renal tissue (Figure 2A). CK2 $\alpha / \alpha^{\prime}$ staining in tumor core samples tended to show a prominent nuclear staining (Figure 2A). When analyzing the TMA results according to the tumor Fuhrman grade, we observed that the mean H-Score values for nuclear $\mathrm{CK} 2 \alpha / \alpha$ ' staining were significantly higher in tumors than in normal counterpart renal tissue whereas cytosolic CK $2 \alpha / \alpha$ ' staining in tumor samples decreased slightly although the differences were not statistically significant (Figure 2B, left panel). These results would agree with a specific nuclear accumulation of $\mathrm{CK} 2 \alpha / \alpha^{\prime}$ in ccRCC, as reported recently [27]. It is worth to mention that the results in Figure $2 \mathrm{~B}$ show the expression levels of both catalytic subunits in two different cellular compartments using the H-score method, while in the western blot assays shown in Figure 1 CK $2 \alpha$ and CK2 2 ' levels were analyzed separately but in a total cellular lysate. Therefore, the augmented values for the CK2 $\alpha$ ' subunit observed in Figure 1 might relate to the contribution of the augmented expression of this subunit in the nuclei.

In contrast to $\mathrm{CK} 2 \alpha / \alpha$, nuclear $\mathrm{CK} 2 \beta$ staining showed only moderate increases in tumor samples whereas cytosolic CK2 $\beta$ showed a significant decline in G1/G2 that was particularly marked in G3/G4 samples (Figure 2C, left panel). When the samples were grouped according to their tumor stage (pT1/pT2 and pT3/pT4) the trend of changes in $\mathrm{CK} 2 \alpha / \alpha$ ' mirrored that detected when grouped by grade. A similar observation was evident concerning CK2 $\beta$ levels (Figure 2B and 2C).

The behavior of CK2 $\beta$ subunit in tumors has been less explored, in contrast to the well characterized increases in CK2 catalytic subunits $\left(\mathrm{CK} 2 \alpha / \alpha^{\prime}\right)$ in diverse types of carcinomas. A critical point addressed in our study was if the profile of CK $2 \beta$ changes mirrored or not that of CK2 catalytic subunits as indicative of potential changes in tetrameric CK2 form. Our results would agree with increases in CK2 holoenzyme in the initial stages of ccRCC but not in the more advanced tumors, regardless of the changes in the individual CK $2 \alpha$ or CK $2 \alpha$ ' subunits, since both were found increased at the initial and advanced ccRCC tumor stages.

\section{Downregulation of CK2 $\beta$ in $\mathrm{HK}-2$ and 786-O renal cell lines decreases specifically the activity of CK2 holoenzyme}

Human renal cell line 786-O is a widely used model of human ccRCC cells, whereas HK-2 cells are a well-established model of non-malignant human kidney PTC cells. Both cell lines express the two CK2 catalytic subunits (CK2 $\alpha$, and CK2 $\alpha$ ') as well as the regulatory CK2 $\beta$ (Supplementary Figure 3 ). However, the levels of CK2 $\alpha$ and CK2 $\alpha$ ' were slightly higher (1.4 to 1.7-fold) in 786-O cells than in HK-2 cells whereas CK2 $\beta$ levels were similar. Increases in the ratios between CK2 catalytic and regulatory subunits have also been observed in metastatic breast cancer cell lines as compared with non-malignant mammary gland epithelial cells [36].

Lentiviral transduction of shRNA-CK $2 \alpha$ caused the stable silencing of $\mathrm{CK} 2 \alpha$ to about $40-50 \%$ of the initial value both in 786-O and HK-2 cell lines, as compared with their respective empty-vector transduced cells (shCV) (Figure 3A). CK2 $\alpha$-silencing had minor consequences in $\mathrm{CK} 2 \alpha$ ' levels but was accompanied with a decrease in CK2 $\beta$ levels to about $60 \%$ in $786-\mathrm{O}$ and to $40 \%$ in $\mathrm{HK}-2$ cells. Decreases in CK2 $\beta$ levels in response to CK2 $\alpha$ silencing have also been reported previously in other cell types due to the instability of CK $2 \beta$ once free $[37$, 38]. Lentiviral transduction of shRNA-CK $2 \beta$ provoked a decrease in CK2 $\beta$ to about $30 \%$ of the initial value in $786-\mathrm{O}$ and to less than $10 \%$ in HK-2 cells. As observed in other cell lines $[37,38]$, CK2 $\beta$-silencing caused a decrease in $\mathrm{CK} 2 \alpha$ '. In contrast, CK $2 \alpha$ levels were essentially unaffected in CK2 $\beta$-silenced cells.

The consequences of the changes in the cell levels of CK2 catalytic/regulatory subunits on its activity was first determined in cell extracts using an in-gel CK2 activity assay with $\beta$-casein as substrate. As shown in Figure 3B, the extent of $\beta$-casein phosphorylation detected in these assays correlated with the amount of catalytic subunit, 

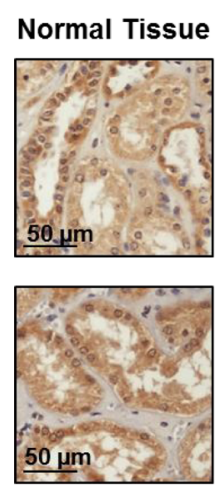

11679 R1 A
G1
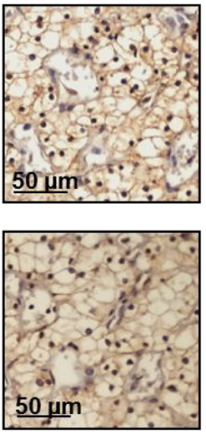

11679 R1 A
G2
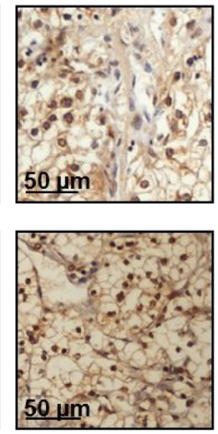

7674
G3
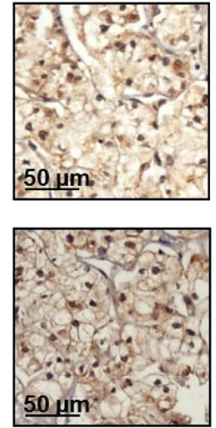

27234 R1
G4
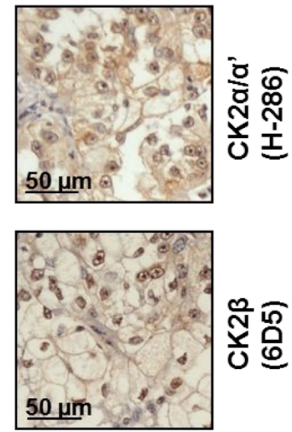

24077
B

CK2 $\alpha / \alpha$ ' Führman's Grade

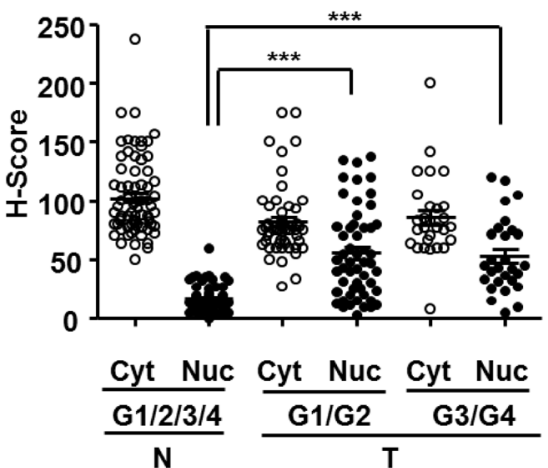

C

CK2 $\beta$ Fuhrman's Grade

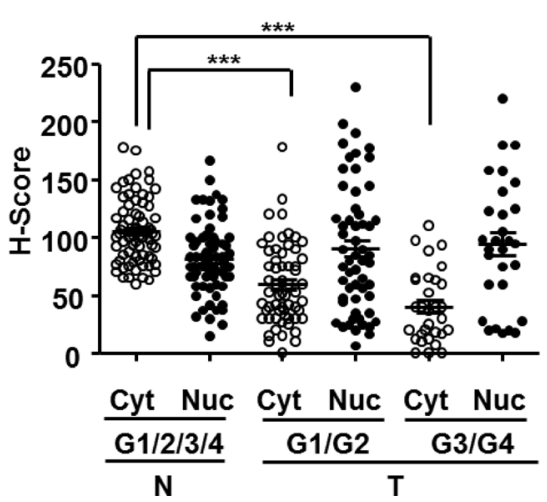

CK2 $\alpha / \alpha^{\prime}$ Tumour Stage

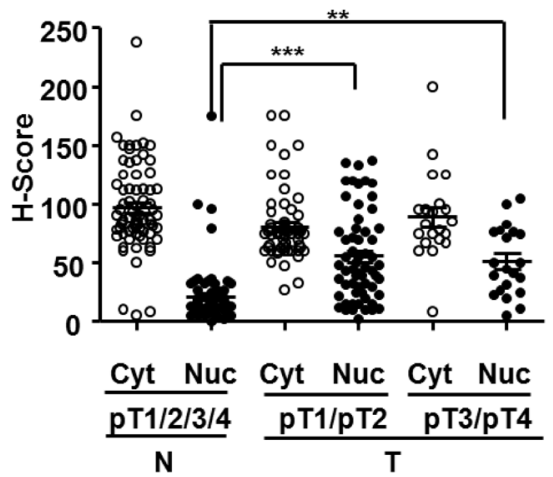

\section{CK2 $\beta$ Tumour Stage}

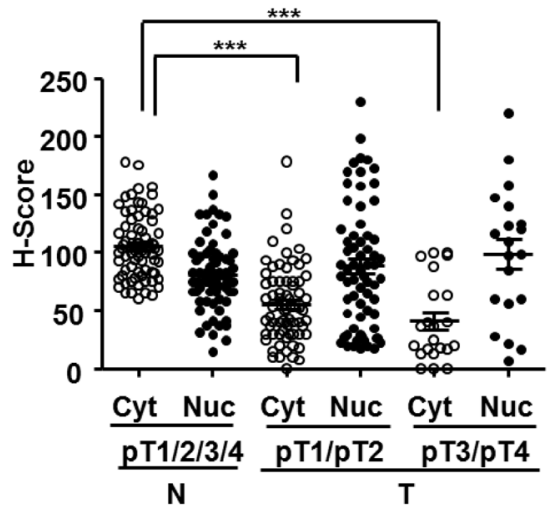

Figure 2: Expression of CK2 subunits in the 98 ccRCC samples embedded in Tissue Microarrays (TMAs). (A) CK2 $\alpha$ and CK2 $\beta$ levels in tumor tissue samples classified according their nuclear Fuhrman Grade. The pictures correspond to representative samples from biopsies of patients affected by ccRCC with different Fuhrman grades (G1 to G4) as well as a sample of unaffected normal kidney counterpart out of the 98 samples included in the TMA. CK2 subunits (brown) were detected by a colorimetric method and the samples were counterstained by haematoxylin as was indicated in materials and methods. (B), (C) Scatter plot of CK2 $\alpha$ and CK2 $\beta$ expression levels in the nuclei (Nuc) and cytoplasm (Cyt) of the 98 ccRCC samples included in TMAs classified by their Fuhrman nuclear grade (G1/G2, G3/ G4) (left hand panels) and stage (pT1/pT2, pT3/pT4) (right hand panels). The samples were evaluated using the H-score semi-quantitative method described previously. H-score values obtained were analyzed by one-way ANOVA using the Bonferroni's correction algorithm. $\left.\left({ }^{* *}\right),{ }^{* * *}\right)$ denote $p<0.01$ and $p<0.001$, respectively. Non-significant differences are not indicated. 
either CK2 $\alpha$ or CK2 $\alpha^{\prime}$ detected by western blot. We have previously shown that the standard CK2 peptide (CK2tide) is a substrate for both CK2 holoenzyme and free catalytic subunits whereas the phosphorylation of the eIF2 $\beta$ derived peptide (eIF2 $\beta$-tide) shows an absolute requirement for $\mathrm{CK} 2 \beta$ [39]. CK2 activity assays in crude cell extracts from both the HK-2 and the 786$\mathrm{O}$ cell lines showed that the negative consequences of CK2 $\alpha$-silencing were more marked than those of CK2 $\beta$-silencing when using the CK2-tide whereas those caused by CK $2 \beta$-silencing were more evident on eIF $2 \beta$ tide (Figure $3 \mathrm{C}$ ). The combined data obtained on $\mathrm{CK} 2$ subunits content and activity assays indicate that $\mathrm{CK} 2$ present in CK2 $\alpha$-downregulated cells would correspond to CK2 holoenzyme, either tetramers or other higher rank structures, whereas the CK2 $\beta$-downregulated cells, in particular the HK-2/shCK $2 \beta$ cells, would contain low amounts of CK2 holoenzyme which would be responsible for the activity on the eIF $2 \beta$-tide.

We also verified the reduction of CK2 activity in the downregulated cells by means of the endogenous substrate Akt1 Ser129 [40]. Its phosphorylation was reduced in HK-2 cells by down-regulation of $\mathrm{CK} 2$ subunits, especially CK2 $\beta$ (Figure 3D), suggesting that it requires the holoenzyme form of $\mathrm{CK} 2$. This agrees with that observed recently in $\mathrm{C} 2 \mathrm{C} 12$ myoblast cell line after knocking out CK2 subunits [38]. In the case of 786-O cells, the mainly expressed Akt isoform is Akt2, which is not phosphorylated by CK2 [41], thus phosphorylation of Akt1 at Ser129 was hardly appreciable; nevertheless it was also reduced by down-regulation of CK2 subunits, especially of CK $2 \beta$.

\section{CK2 $\alpha$ - or CK2 $\beta$-downregulation alters the expression of EMT markers in HK-2 and 786-O cells}

Recent reports have shown CK2 holoenzyme activity contributes to maintaining a normal epithelial morphology in breast cell lines, as CK2 $\beta$ silencing induced an epithelial-to-mesenchymal transition (EMT) phenotype $[24,36,42]$ associated with decreases in E-cadherin and increases in snaill and vimentin levels. We decided to check if the decreases in CK2 holoenzyme caused by downregulation of either CK $2 \alpha$ or CK $2 \beta$ altered the protein levels of these EMT markers in HK-2 and 786-O renal cell lines with respect to their corresponding controls (shCV). Control HK-2 cells expressed significant levels of E-cadherin whereas 786-O cells expressed very low levels, which were only detectable after long exposure of the blot (Figure 4A). In both cell lines, silencing of CK $2 \alpha$, and in particular of CK2 $\beta$, caused a marked decrease in E-cadherin. Snaill is a well-known repressor of E-cadherin expression whose stability in MCF10A cells is controlled through hierarchical phosphorylation by $\mathrm{CK} 2$ and GSK $3 \beta$, a process that depends strongly on CK2 $\beta$ levels [24]. In agreement with this, CK2 $\beta$ silencing caused an increase in snaill protein levels in 786-O and in HK-2 cells although both basal and stimulated levels were more robust in 786-O cells (Figure 4A). Intermediate increases in snaill were detected in both cell lines after CK $2 \alpha-$ silencing what agrees with the intermediate decreases in E-cadherin levels detected after silencing this subunit. Vimentin is a positive EMT marker whose expression is enhanced by snail1 [43]. Control HK-2 and 786-O cells expressed detectable levels of vimentin, which increased in the CK2-silenced cells.

The most dramatic effects on these EMT markers were exerted by CK2 $\beta$ down-regulation and they were particularly evident on E-cadherin and snaill in the HK-2 cell line. The effect of rescuing CK2 $\beta$ levels in HK-2/ shCK $2 \beta$ cells was then studied in order to confirm the specificity of the effects on E-cadherin and snaill. To this purpose, HK-2 cells were transfected with a vector containing a synthetic CK2 $\beta$ optimized coding sequence carrying base mutations that would weaken its recognition by the shCK $2 \beta$ without introducing any mutation into the CK $2 \beta$ expressed protein. Overexpression of CK2 $\beta$ in control $\mathrm{HK}-2 / \mathrm{shCV}$ cells did not alter snaill and E-cadherin levels, whereas an increase in E-cadherin and a decrease in snaill levels were detected in the transfected HK-2/shCK2 $\beta$ cells (Supplementary Figure 4). These results agree with those reported previously in MCF10A cells [24].

Previous reports have shown that $\mathrm{HIF} \alpha$ is upregulated in ccRCC and could be involved in the induction of an EMT phenotype in renal cell lines $[44,45]$. On the other hand, CK2 activity has been shown to affect HIF-1 $\alpha$ transcriptional activity and to stabilize HIF-1 $\alpha$ protein $[15,16,46]$. Therefore we decided to explore the potential effects of CK2 holoenzyme downregulation through $\mathrm{CK} 2 \alpha$ - or $\mathrm{CK} 2 \beta$-silencing on $\mathrm{HIF} \alpha$ expression in HK-2 and 786-O cells under the normoxic conditions used throughout our studies. HIF-1 $\alpha$ levels, the sole isoform of HIF $\alpha$ expressed in HK-2 cells, were very low in control cells, did not essentially vary in $\mathrm{CK} 2 \alpha$-silenced cells but tended to increase in CK2 $\beta$ silenced HK-2 cells (Figure 4B). On the other hand, 786-O cells are known to express only the HIF-2 $\alpha$ isoform. HIF$2 \alpha$ levels did not change in CK $2 \alpha$-silenced cells but were significantly higher in CK2 $\beta$-silenced 786-O cells.

\section{CK2ß-downregulation affects STAT3 phosphorylation in HK-2 and 786-O cells}

STAT3 phosphorylation has been shown to affect HIF-2 $\alpha$ levels in 786-O cells and HIF-1 $\alpha$ and HIF$2 \alpha$ in Caki-1 renal cancer cells $[11,47]$, and STAT3 phosphorylation at Tyr705 and Ser727 residues is increased in ccRCC tumors [13]. Previous reports have shown that exposure of cells to CK2 chemical inhibitors (which block the activity of both CK2 holoenzyme and 
free catalytic subunits) TBB or CX-4945 diminished p-STAT3 Tyr705 [17, 37] as well as p-STAT3 Ser727 phosphorylation in response to different stimuli $[18,19]$. More recently, recombinant human CK2 holoenzyme has been shown to phosphorylate 'in vitro' recombinant human STAT3 on Ser727 but the potential role of CK2 $\beta$ in regulating STAT3 phosphorylation, in particular at Ser727, was not evaluated [48]. Hence, we decided to determine if CK2 $\beta$ affected p-STAT3 Tyr705 and p-STAT3 Ser727 levels in the cultured renal cells.
In HK-2 cells p-STAT3 Tyr705 levels tended to increase in CK2 $\alpha$-silenced cells and in particular in CK2 $\beta$-silenced cells (Figure 5). In contrast p-STAT3 Ser727 levels tended to decrease after CK2 $\alpha$ silencing and decreased significantly after CK2 $\beta$ silencing. Downregulation of CK $2 \alpha$ did not significantly alter STAT3 phosphorylation at Tyr705 in 786-O cells whereas CK2 $\beta$ downregulation caused a small but significant increase in p-STAT3 Tyr705. Interestingly, in this cell line downregulation of $\mathrm{CK} 2 \alpha$ also caused a small decrease in
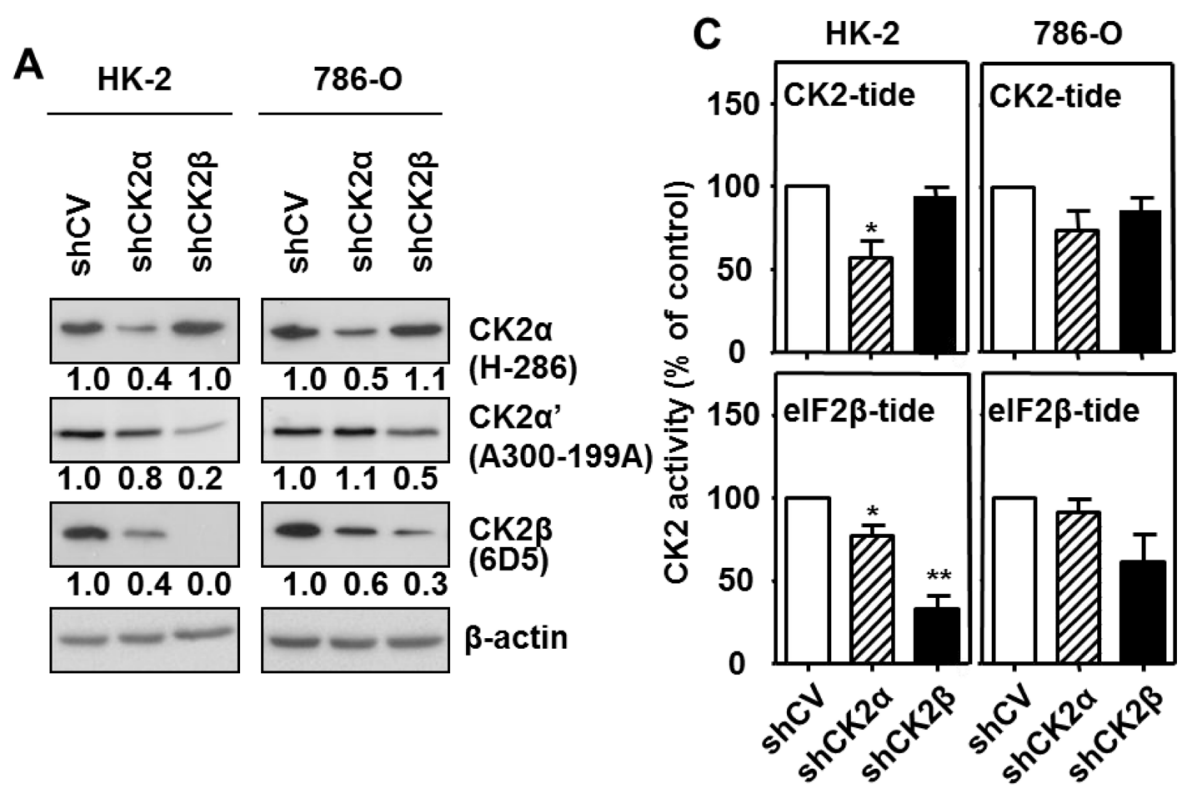

B

D
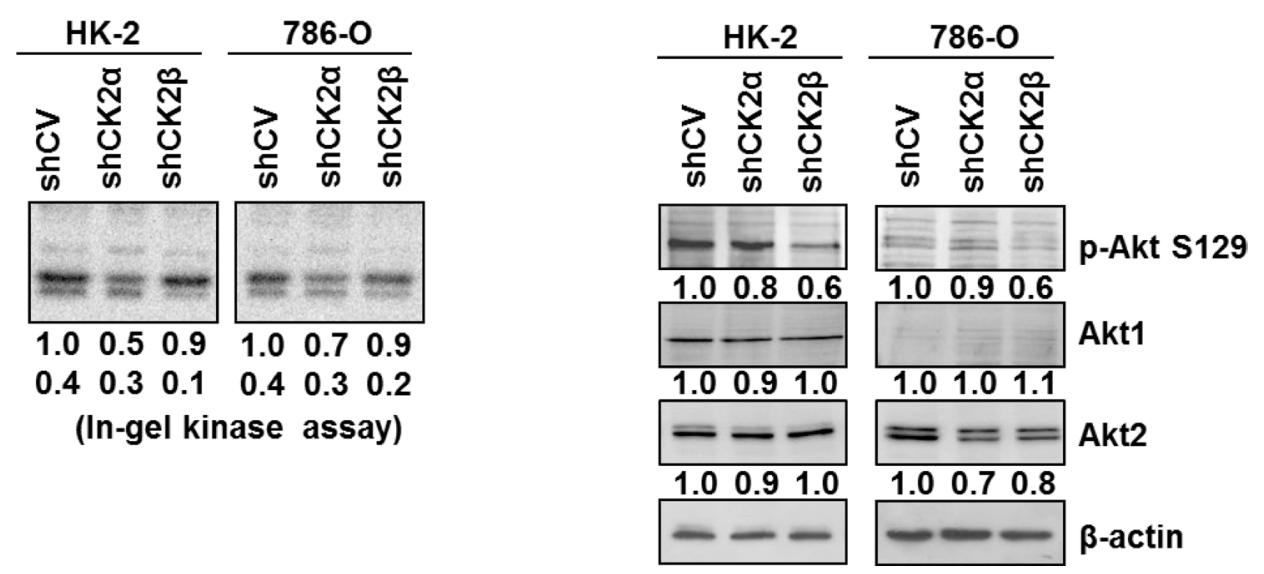

Figure 3: Effects of CK2 $\alpha$ or CK2 $\beta$-downregulation on CK2 subunits levels and CK2 activity in HK-2 and 786-O cell lines. (A) Western blot analysis of CK $2 \alpha$, CK2 $\alpha$ ' and CK2 $\beta$ expression levels in HK-2 and 786-O cells lines silenced for either CK2 $\alpha$ or CK2 $\beta$ subunits. The type of antibody used to detect each CK2 subunit is indicated in parenthesis. Values below each band correspond to the relative subunit expression level respect to their corresponding control cell line (either HK-2 shCV or 786-O shCV). (B) In-gel CK2 activity assay with $\beta$-casein as substrate. (C) CK2 activity of silenced cell lines using either the CK2-tide (phosphorylated by the holoenzyme and catalytic subunits) or the eIF2 $\beta$-tide (phosphorylated by CK2 holoenzyme). Data are represented as mean $+/-$ SEM. (D) Effects of CK2 $\alpha$ or CK2 $\beta$-downregulation on Akt1 phosphorylation at Ser129. Akt1 phosphorylation at its Ser129 (p-Akt S129) and total Akt1 and Akt 2 levels were detected in cell extracts from HK-2 and 786-O cells lines silenced for either CK2 $\alpha$ or CK2 $\beta$ subunits by western blot using specific antibodies. Values below each band correspond to the relative protein expression level respect to their corresponding control cell line (HK-2 shCV and 786-O shCV). 
p-STAT3 Ser727 levels, whereas downregulation of CK2 $\beta$ did not decrease them. These results suggest that, unlike the HK-2 cells, the tumorigenic 786-O cells do not depend on CK2 $\beta$ for sustaining p-STAT3 Ser727 levels.

\section{Cytosolic CK2 $\beta$ levels help to refine the prognostic value of pSer727-STAT3 in ccRCC patients}

When the data from the ccRCC TMAs were grouped by Fuhrman grade or stage no differences were found for the CK $2 \alpha / \alpha$ ' subunits, either nuclear or cytosolic, among groups but a clear tendency was observed for high grade and high stage tumors expressing low levels of cytosolic CK2 $\beta$ subunit. In the multivariate analysis, using an $\mathrm{H}$-Score threshold of cytosolic CK2 $\beta$ higher or equal 41 (median value), we observed a non-significant correlation $(p=0.703)$ with patient survival, which indicates that cytosolic CK2 $\beta$ (CK2 $\beta$ cyt) by itself is not useful as a prognostic biomarker of ccRCC. We have previously demonstrated that p-STAT3 Ser727 is an independent prognostic factor for ccRCC patients [13]. Since we have now observed that CK2 affects STAT3 phosphorylation we decided to evaluate whether a correlation between CK2 subunits expression and p-STAT3 Ser727 levels exists.

When analyzing all patients together, we observed a negative but non-significant correlation between p-STAT3 Ser727 and cytosolic CK2 $\beta$ with Spearman Index of -0.057. Although the correlation was weak between both factors, we aimed to explore the impact, if any, of CK2 2 cyt higher or equal 41 (median value) on the survival profile of patients with p-STAT3 Ser727 levels $>100$ or $<100$, which were previously correlated with poor or good prognosis, according to patient survival, respectively [13]. We observed that the worst possible combination corresponds to p-STAT3 Ser727>100, as reported, with no

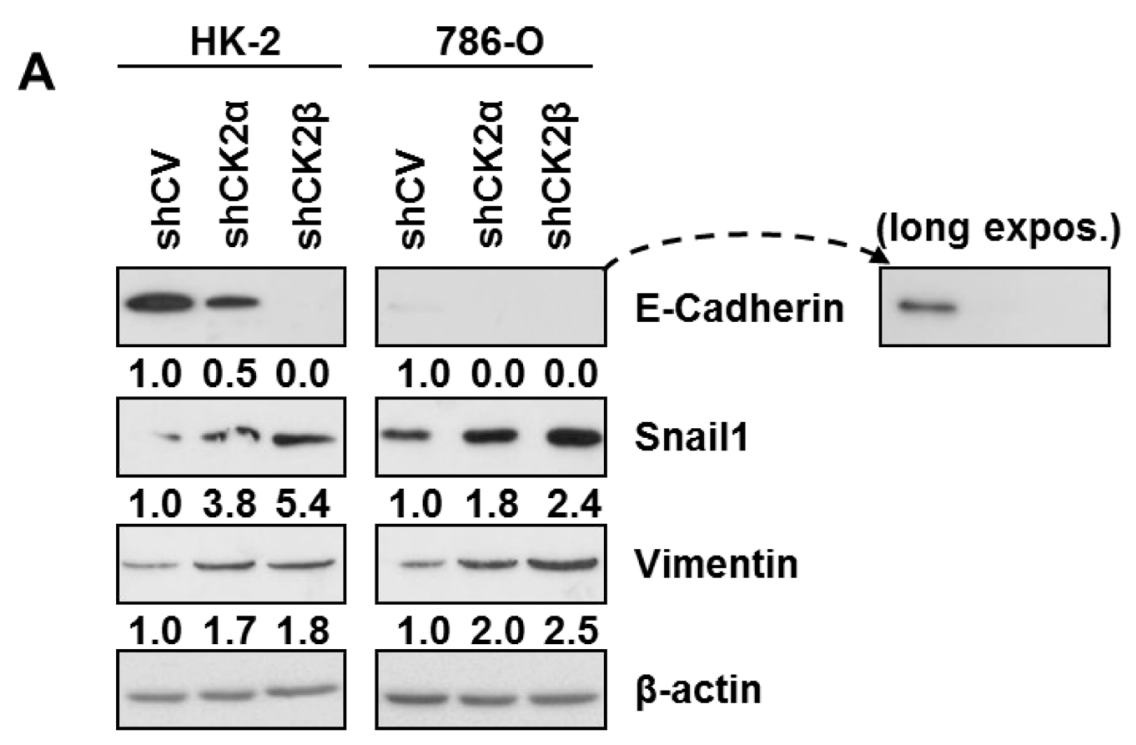

B

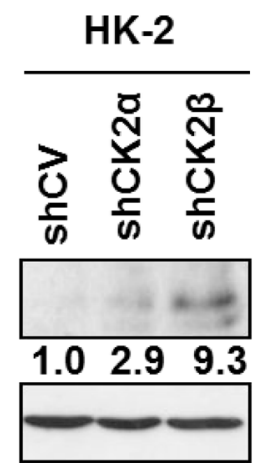

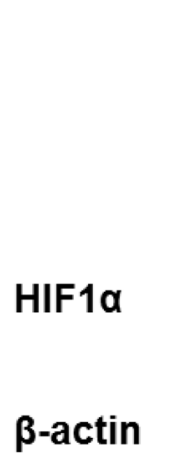

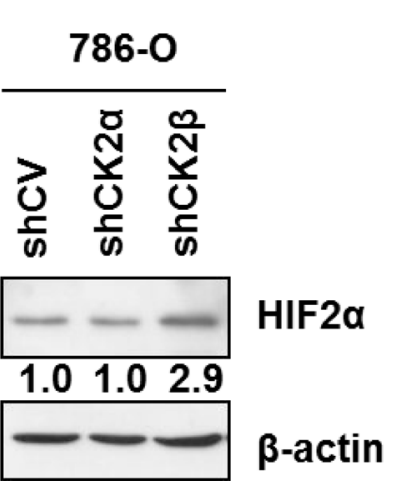

Figure 4: Expression of EMT markers and HIFa in HK-2 and 786-O cells silenced for CK2 subunits. (A) Western blot analysis of the epithelial (E-cadherin) and mesenchymal markers (Vimentin, Snail1) in HK-2 and 786-O cell lines silenced for either CK2 $\alpha$ or CK2 $\beta$ subunits. Values below each band represent the relative protein expression level respect to their corresponding control cell line (HK-2 or 786-O shCV). (B) Effect of CK2 $\alpha$ or CK2 $\beta$-downregulation on the relative expression of HIF $1 \alpha$ in HK-2 cells and of HIF $2 \alpha$ in 786-O cells. Values below each band represent the relative protein expression level respect to their corresponding control cell line (HK-2 or $786-\mathrm{O}$ shCV). 
major contribution of CK2 $\beta$ cyt, since Kaplan Meier curves were alike when CK2 $\beta$ cyt was $<41$ or $>41$ (Figure $6 \mathrm{~A}$ ). Accordingly, we could say that when taking all the patients into consideration, without any kind of stratification, CK2 $\beta$ cyt does not add extra prognostic information to what the high levels of p-STAT3 Ser727 alone predict, regarding poor patient survival. Nevertheless, it is remarkable to observe that for patients with low p-STAT3 Ser727 levels, thereby with good prognosis according to this biomarker, those with low CK2ßcyt levels $(<41)$ (Figure $6 \mathrm{~A})$ exhibited a similar survival rate than patients with high pSer727-STAT3 levels. When patient represented in Figure 6A corresponding to the pSer727-STAT3 $>100 /$ CK2 $\beta$ cyt $>41 ; \quad$ pSer727-STAT3 $>100 /$ CK2 $\beta$ cyt $<41$ and p-STAT3 Ser727 $<100 / C K 2 \beta c y t<41$ groups were combined (COMB2), significant statistical differences $(p=0.043)$ appeared with the p-STAT3 Ser727<100/ CK2 $\beta$ cyt $>41$ patient group (COMB1) (Figure 6B). Accordingly, we can say that CK2 $\beta$ cyt refines the prognostic value of p-STAT3 Ser727 in patients with apparent good prognosis according to their low p-STAT3 Ser727 levels.

The prognostic value of p-STAT3 Ser727 was highly significant and even more pronounced in high-risk patients, were survival after 10-year follow-up was HR $=3.32(95 \% \mathrm{IC} 1.26-8.71) p=0.014$, by a multivariate analyses [13]. When analyzing the prognostic value of the combined biomarkers in separated high- and low-risk groups of patients, we observed that while in the lowrisk patients no significant differences $(p=0.850)$ were observed between COMB1 and COMB2 markers (Figure $6 C)$, a striking significant difference $(p=0.031)$ was observed for patients in the high-risk group according to COMB1 or COMB2 markers (Figure 6D). Kaplan Meier curves indicated that patients with p-STAT3 Ser727<100/ CK2 $\beta$ cyt $>41$ (COMB1) were free of disease with no events in 10 years post-surgery, while those with p-STAT3 Ser $727<100 /$ CK $2 \beta$ cyt $<41$ were falling to profiles similar to patients with high p-STAT3 Ser727 levels. To sum up, our results indicate that $\mathrm{CK} 2 \beta$ cyt can refine the prognostic value of p-STAT3 Ser727 in patients within the high risk group, and that patients with high CK2 $\beta$ cyt have better prognosis than those with low CK2 $\beta$ cyt levels when p-STAT3 Ser727 are low $(<100)$.

\section{DISCUSSION}

Different reports have shown a link between the expression of CK2 catalytic subunits (CK2 $\left.\alpha / \alpha^{\prime}\right)$ and diverse types of carcinomas [26-32, 49, 50], The results of our study agree with an increase in nuclear CK2 catalytic subunits content in ccRCC, as previously reported in other human cancers $[27,28,32,49]$. On the other hand, studies on the status of the regulatory CK2 $\beta$ in cancer are rather scarce. Our data on western blot analysis partially agree with those of a previous report, published two decades ago [25], since we detected increased total CK2 $\beta$ levels in the G1/G2 tumor samples. However, this does not hold for the ccRCC samples corresponding to more advanced tumors (G3/G4 and pT3), which showed decreases in total CK2 $\beta$ levels when analyzed by western blot or more specifically in cytosolic CK $2 \beta$ when analyzed by immunohistochemistry. Increased ratios between catalytic
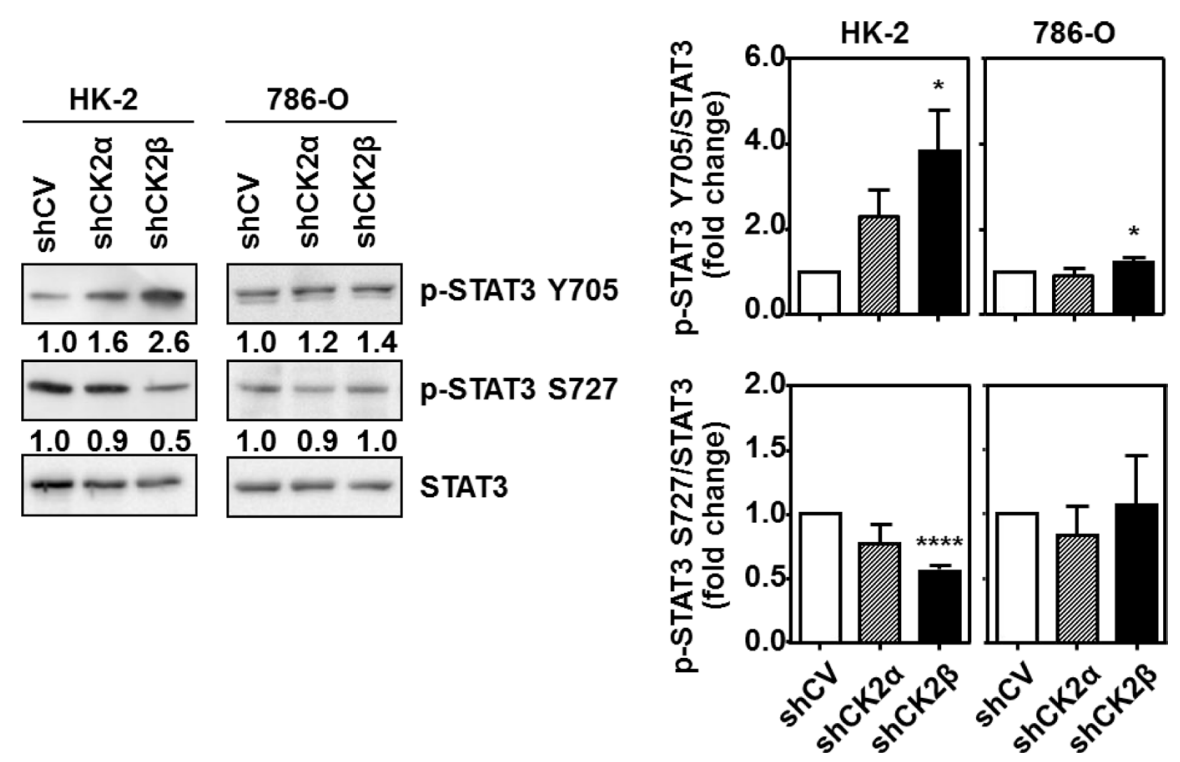

Figure 5: Effects of CK2 $\alpha$ or CK2 $\beta$-downregulation on STAT3 phosphorylation in HK-2 and 786-O cells. STAT3 phosphorylation at either Tyr705 (p-STAT3 Y705) or Ser727 (p-STAT3 S727) and total STAT3 levels were detected in cell extracts from HK-2 and 786-O cells lines silenced for either CK2 $\alpha$ or CK2 $\beta$ subunits by western blot using specific antibodies. The plots indicate the mean values of the densitometries of the p-STAT3 bands relative to the total STAT3 levels obtained in four different experiments. Data are represented as mean \pm SEM. Values were analyzed by Student's $t$-test. $\left(^{*}\right)$ and $\left(^{* * * *}\right)$ denote $p<0.05$ and $p<0.0001$, respectively. 
and regulatory subunits, due in part to decreased levels of the regulatory $\mathrm{CK} 2 \beta$ subunit, has also been detected previously in five out of a set of fifteen human renal cell carcinoma cell samples analyzed by western blot [26] Moreover, a marked downregulation of CK2 $\beta$ mRNA expression in all tumor samples compared with normal renal tissue was detected in that study [24] suggesting an important posttranscriptional regulation of CK2 subunits in RCC. In contrast to this, a more recent study [27] has shown that $\mathrm{CK} 2 \beta$ mRNA expression was slightly higher in ccRCC than in renal cortex but no correlation was observed between CK2 $\beta$ mRNA expression and clinicopathological factors. However, the protein levels of CK2 $\beta$ were not determined in these studies. Our results show low levels of cytosolic CK2 $\beta$ subunit in high grade and high stage tumors, as discussed later in more detail.

The asymmetric changes in CK2 subunits detected in the ccRCC samples would reflect alterations in the
A p-STAT3 S727 \& CK2ßcyt subgroups
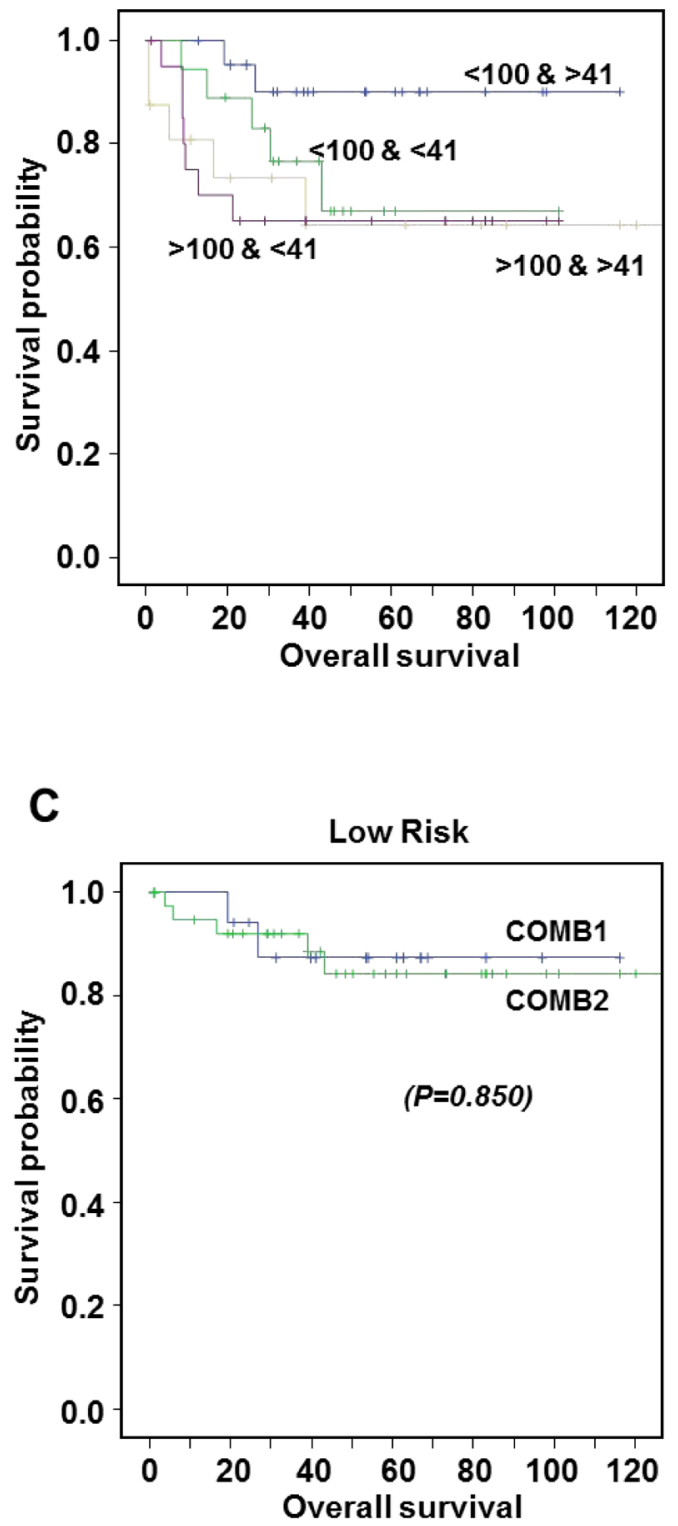

B
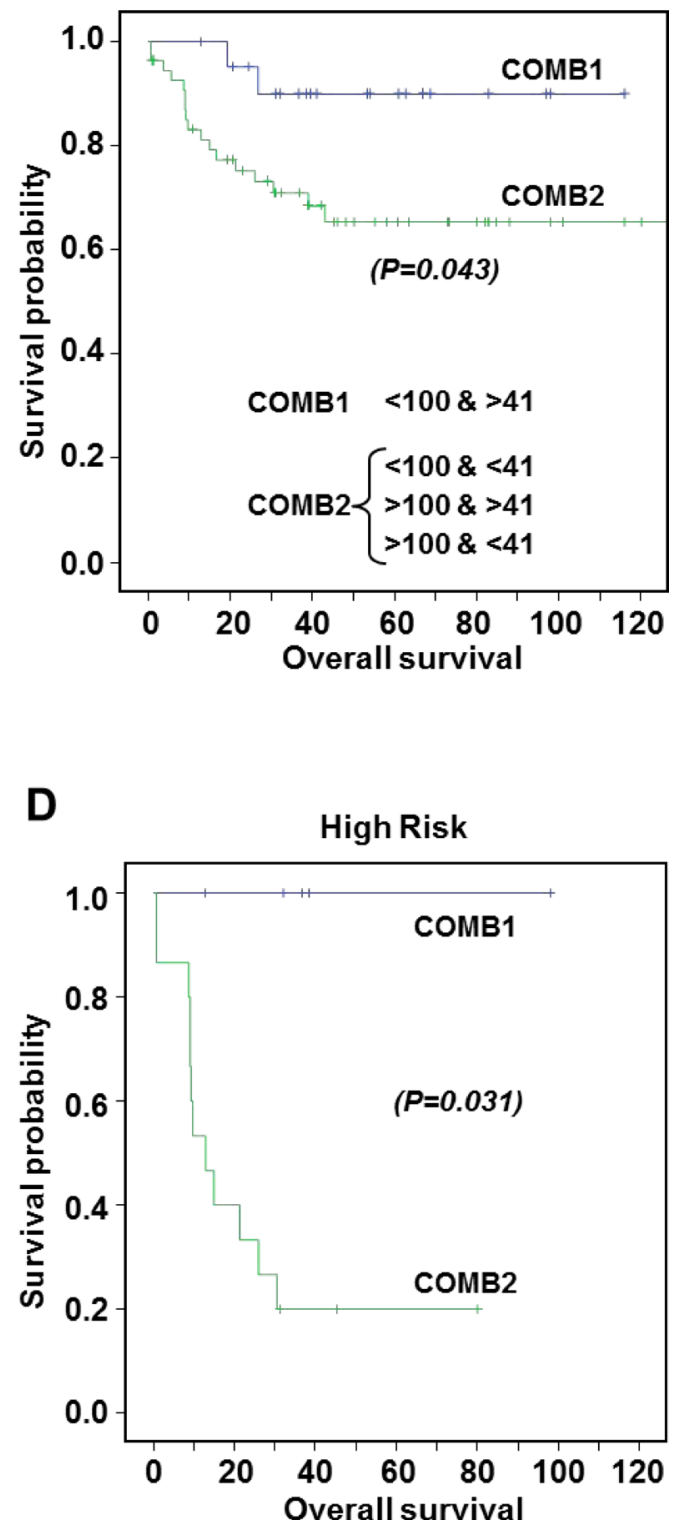

Figure 6: Kaplan-Meier estimates of 120-months overall survival according to combinations of p-STAT3 Ser727 and CK2 $\beta$ cyt expression levels. (A) Patients exhibiting p-STAT3 S727 levels $<100$ and $>100$, correlating with good and bad prognosis, respectively [13], were subgrouped according to their CK2 $\beta$ cyt levels were above or below 41 (median value). Metastatic patients have been excluded. (B) COMB1 corresponds to patients exhibiting p-STAT3 S727 levels $<100$ and CK2 $\beta$ cyt $>41$. COMB2 includes the three other groups. No significant differences were observed among groups in COMB2. Statistical significant differences were observed between COMB1 and COMB2. (C, D) Kaplan-Meier estimates of 120-months overall survival according to COMB1 or COMB 2 for Low Risk (C) and High Risk (D) patients. Statistical significant differences were observed between COMB1 and COMB2 in the High Risk group. 
ratio of CK2 catalytic subunits incorporated into $\mathrm{CK} 2$ holoenzyme, what could alter the targeting of a subset of CK2 specific substrates [51, 52]. As reported previously for normal human breast epithelial cells (MCF10A cells) [24], depletion of CK2 $\beta$ in HK-2 and 786-O cells altered the expression of EMT markers, decreasing E-cadherin and increasing snaill and vimentin levels. These effects, together with the specific decrease in CK2 activity on the eIF2 $\beta$-tide, without altering that on the CK2-tide, would support a marked specific decrease in CK2 holoenzyme in the silenced cells. On the other hand, down-regulation of CK2 $\alpha$ induced a partial change in these parameters, indicative of intermediate decreases in CK2 holoenzyme. Altogether, our results suggest that the decreases in CK2 $\beta$ might contribute to the EMT in RCC tumors, a process suggested to play a significant role in disease recurrence, invasion and metastasis [6].

It is well known that ccRCC are highly vascularized tumors. Accordingly, angiogenesis is considered fundamental to ccRCC pathogenesis and HIF $\alpha$ is upregulated in these tumors $[8,9]$. Protein kinase CK2 has been shown to affect HIF-1 $\alpha$ transcriptional activity [46] and to stabilize HIF-1 $\alpha$ protein either by phosphorylation or destabilization of VHL protein $[15,16]$ or through the histone deacetylase (HDAC)-mediated pVHL downregulation pathway [14]. Interestingly, free recombinant human $\mathrm{CK} 2 \alpha$ is able to phosphorylate the N-terminal acidic domain of pVHL [53] and CK2 catalytic subunits, rather than $\mathrm{CK} 2$ holoenzyme, were found important for triggering the HDAC-mediated pathway in HeLa cells [14]. Nevertheless, it is interesting to remark that in the present study the effects of CK2-silencing on HIF $\alpha$ levels were detected under normoxic conditions and HIF-2 $\alpha$ increased in the VHL-deficient 786-O cells, what indicates that these effects are exerted, at least in part, through VHL-independent mechanisms.

Activator of transcription STAT3 is a potent regulator of HIF-1 $\alpha$ and HIF-2 $\alpha$ expression [11] and STAT3 phosphorylation at Tyr 705 and Ser 727 residues is increased in ccRCC tumors [13]. Previous reports have shown that CK2 modulates STAT3 activation since TBB and CX-4945 (two CK2 chemical inhibitors that block the activity of both CK2 holoenzyme and free catalytic subunits) diminished STAT3 phosphorylation on Tyr705 [17, 37] and Ser727 $[18,19]$ residues triggered in response to different stimuli in cultured cells. STAT3 phosphorylation at Tyr705 is catalyzed by Jak1 or Jak2 kinases and both are activated by binding to CK2 [17]. Our results would point to CK2 $\alpha$ rather than CK2 holoenzyme as the positive regulator of Tyr705-STAT3 phosphorylation since it increased upon CK2 $\beta$ downregulation both in HK-2 and 786-O cell lines. It must be emphasized that our present study is based on downregulation CK2 $\beta$ which did not result in decreases on CK2 activity measured with the CK2-standard peptide in contrast to that caused by the CK2 chemical inhibitors used in most of other previous studies.
As far as STAT3 phosphorylation on Ser727, overexpression of CK2 has been shown to decrease it in C6 glioma cells through a mechanism involving CK2 activation of protein phosphatase PP2A [54]. On the other hand, a recent report has shown that recombinant human $\mathrm{CK} 2$ holoenzyme is able to directly phosphorylate 'in vitro' recombinant human STAT3, but the potential requirement of CK2 $\beta$ for this phosphorylation was not evaluated [48]. These authors also indicate that STAT3 phosphorylation on Ser727 in chronic lymphocytic leukemia (CLL) is more elaborate since it requires the assembly of a CK2/CD5/B-Cell Linker Protein (BLNK)/STAT3 complex [48]. This may underlay a unique targeting mechanism accounting for the phosphorylation of a residue, STAT3 Ser727, which is devoid of the canonical $\mathrm{CK} 2$ consensus. Interestingly, CD5 is known to interact with $\mathrm{CK} 2$ through contacts between the cytoplasmic domain of $\mathrm{CD} 5$ and the N-terminal region of CK2 $\beta$ [55]. The existence of protein complexes acting as a bridge between CK2 and STAT3 in renal cells is unknown. However, our results show that CK2 $\beta$ is needed for the constitutive phosphorylation of STAT3 on Ser727 in HK-2 cells, but this does not hold for 786-O cells, whose constitutive pSer727-STAT3 levels do not seem to depend on CK2 $\beta$. Although the underlying reason is unknown, it clearly shows a different behavior between the non-tumorigenic HK-2 and the tumorigenic 786-O cell lines concerning the potential mechanisms involved in STAT3 phosphorylation at Ser727.

We have recently observed that STAT3 phosphorylation both at Tyr705 and Ser727 residues is increased in ccRCC tumor samples, and that Ser727 is an independent prognostic factor in ccRCC [13]. In the present study we observed that the combination of p-STAT3 Ser727 and either nuclear or cytosolic CK $2 \alpha / \alpha$ ' did not improve the prognostic values of p-STAT3 Ser727. No significant correlation was found between cytosolic CK2 $\beta$ (CK2 $\beta$ cyt) levels with patient survival, which indicates that CK2 $\beta$ cyt by itself is not useful as a prognostic biomarker. However, we have observed that CK2 $\beta$ cyt levels are instrumental to refine prognosis of patients with low p-STAT3 Ser727. In this group of patients, CK2 $\beta$ cyt $>41$ discriminates patients free of disease for a period of 10 years from those with CK2 $\beta$ cyt $<41$, which behave as the patients with p-STAT3 Ser727 levels over 100. Therefore, CK2 $\beta$ cyt is useful to fully assess the prognosis of patients with low p-STAT3 Ser727, because discriminates well among patients with different prognosis requiring different clinical follow-up that would be otherwise treated equally.

\section{MATERIALS AND METHODS}

\section{TMAs and human biopsies samples}

Tissue Microarrays (TMAs) were provided by the Department of Pathology, Vall d'Hebron Hospital, Barcelona, Spain. TMAs were constructed using the Advanced Tissue Arrayer (Chemicon International) 
as has been detailed in previous reports [13, 56]. 98 samples of renal cell carcinomas from patients subjected to a nephrectomy were included in those TMA to evaluate the expression of different biomarkers by immunohistochemistry (IHC). 21 samples from patients affected for ccRCC, which did not coincide with those of the TMA, were available for evaluating the expression of CK2 subunits by western-blot analysis.

\section{Immunohistochemistry}

The tissue samples present in TMA were deparaffinized and an immunoperoxidase staining was used for the IHC analysis. Antigens were retrieved through a citrate buffer treatment $(10 \mathrm{mM}$ sodium citrate, $\mathrm{pH}$ 6.0) in a $95^{\circ} \mathrm{C}$ water bath for $20 \mathrm{~min}$. The endogenous peroxidases were blocked with Peroxidase Blocking Solution $\left(3 \% \mathrm{H}_{2} \mathrm{O}_{2}, 10 \mathrm{~min}\right)$ and subsequently unspecific proteins were blocked for $1 \mathrm{~h}$ at room temperature with $10 \%$ Normal Horse Serum in PBST. The samples were incubated $\mathrm{O} / \mathrm{N}$ at $4^{\circ} \mathrm{C}$ with anti-CK2 $\alpha / \alpha^{\prime}(\mathrm{H}-286$, sc9030, Santa Cruz Biotechnology, which detects CK2 $\alpha$ and CK $2 \alpha$ ' of human origin in IHC analysis of paraffinembedded sections at 1:50 dilution) or anti-CK2 $\beta$ (6D5, sc-12739 1:50 dilution, Santa Cruz Biotechnology) antibodies. After incubation, the reaction of visualization was performed with Real EnVision HRP Rabbit/ Mouse Detection System (DAKO) for $40 \mathrm{~min}$ at room temperature using 3,3'-diaminobenzimide as a chromogen and slides finally were counterstained with haematoxylin. The expression levels of CK2 subunits were evaluated by two independent pathologists using the semi-quantitative method of immune-histo-score (H-score) based on the percentage and intensity of stained cells. Discrepancies were resolved by a concurrent re-examination by both researchers using a double-headed microscope. For each sample, nuclear and cytosolic CK $2 \alpha$ and CK2 $\beta$ expression were evaluated. The intensity score was defined as: $0=$ non appreciable staining in cells; 1 = weak staining; $2=$ moderate staining; $3=$ intense staining. $[\mathrm{H}$-score $=1$ $\times(\%$ weak $)+2 \times(\%$ moderate $)+3 \times(\%$ intense $)$ ranging from 0 to 300]. For each patient an $\mathrm{H}$-score mean of three cores were obtained and used for subsequent statistical analysis. Snapshots were taken with a Leica DFC 500 camera coupled to a Leica DMRB microscope using the Leica Application Suite V4.3 software.

\section{Cell lines and transfections}

Proximal tubule epithelial cell line HK2 (CRL$2190^{\mathrm{TM}}$ ) and human renal adenocarcinoma cell line 786-O (CRL-1932 ${ }^{\mathrm{TM}}$ ) were obtained from the American Type Culture Collection (ATCC). HK-2 and 786-O cells were cultured in Dulbecco's Modified Eagle's Medium (DMEM) supplemented with 10\% fetal bovine serum (FBS), $1 \%(\mathrm{v} / \mathrm{v})$ L-Glutamine, $1 \mathrm{mM}$ sodium pyruvate, $1 \%$ (v/v) Streptomycin and Penicillin at $37^{\circ} \mathrm{C}$ in an incubator.
Stably-silenced cell lines for CK2 $\alpha$ and CK2 $\beta$ subunits (shCK $2 \alpha$ and shCK $2 \beta$ respectively) as well as control (shCV) cell lines were generated by transduction with Sigma Mission ${ }^{\circledR}$ lentiviral Transduction Particles (Sigma-Aldrich) (shCK2 $\alpha$ : NM_177559.2-1895s21c1; shCK2ß: NM 001320.x-823s1c1; shCV: SHC202V) at a final MOI (Multiplicity of Infection) of 2 and followed by a puromycin selection $(1 \mu \mathrm{g} / \mathrm{mL})$ for a week. HK-2 and 786-O stably-silenced cell lines were maintained in complete DMEM medium supplemented with $1 \mu \mathrm{g} / \mathrm{mL}$ of puromycin in a cell incubator.

\section{Tissue and cell lysates and western blot analysis}

Human renal carcinoma tissues were washed with cold phosphate buffered saline (PBS) and lysed in lysis buffer (50 mM Tris/HCl pH 7.7, $150 \mathrm{mM} \mathrm{NaCl}, 15 \mathrm{mM}$ $\mathrm{MgCl}_{2}, 0.4 \mathrm{mM}$ EDTA, $0.5 \%$ Triton X-100, 0.5 mM DTT, $2 \mathrm{mM}$ PMSF, $100 \mu \mathrm{g} / \mathrm{ml}$ protease inhibitors). HK-2 and 786-O cell lines extracts were obtained washing cells with PBS and lysed using the cell lysis buffer (50 mM Tris/ $\mathrm{HCl} \mathrm{pH} \mathrm{7.4,} 150 \mathrm{mM} \mathrm{NaCl}, 1 \%$ triton-X-100, 1 mM DTT, $1 \mathrm{mM}$ PMSF, $1 \mathrm{mM}$ EDTA, $25 \mathrm{mM} \mathrm{NaF}, 0,2 \mathrm{mM} \mathrm{Na}_{2} \mathrm{VO}_{3}$, $2 \mathrm{mM} \mathrm{PPi}, 1 \mu \mathrm{g} / \mathrm{mL}$ protease inhibitors (leupeptin, benzamidin, aprotinin, pepstatin)). Protein concentrations of the extracts were determined by the colorimetric method of Bradford according to the manufacturer's instructions (BioRad). Equal amounts of proteins were loaded in $10 \%$ SDS polyacrylamide gels (SDS-PAGE), subjected to electrophoresis and subsequently electrotransfered to polyvinylidene fluoride membranes (PVDF, Immobilion $\mathrm{P}$, Millipore). Unspecific proteins were blocked in 5\% nonfat dry milk in TTBS $(50 \mathrm{mM}$ Tris/HCl, $\mathrm{pH} 7.4,150 \mathrm{mM}$ $\mathrm{NaCl}$ and $0.1 \%$ Tween-20) for $1 \mathrm{~h}$ at room temperature. Membranes were then incubated overnight with the adequate primary antibodies at $4^{\circ} \mathrm{C}$, rinsed in TTBS and incubated with their respective secondary antibodies conjugated to horseradish peroxidase (HRP). The signal was generated using Lumi-light Western blotting substrate (Roche, GE) and detected by Amersham Hyperfilm ECL (GE-Healthcare) or Chemidoc MP Image System (BioRad, Hercules, CA). Primary antibodies used were: anti-CK2 $\alpha$ H-286 (sc-9030, Santa Cruz Biotechnology), anti-CK2 $\alpha$ 1AD9 (05-1431, Millipore), anti-CK2 $\alpha$ ' (A300-199A, Bethyl Laboratories), anti-CK2 $\beta$ 6D5 (sc12739, Santa Cruz Biotechnology), anti-CK2 $\beta$ (h) (raised in rabbits immunized with whole human recombinant CK2 $\beta$ as described in [57]), anti-p-Akt1 Ser129 (ab133458, EPR6150, Abcam), anti-Akt1 (2938, C73H10, Cell Signaling), Anti-Akt2 (3063, D6G4, Cell Signaling), anti-E-Cadherin (610181, BD Biosciences), anti-Snail1 (3895, L70G2, Cell Signaling), anti-Vimentin (V6389 Sigma-Aldrich), anti-p-STAT3 Tyr705 (4113, M9C6, Cell Signaling), anti-p-STAT3 Ser727(9134, Cell Signaling), anti-STAT3 (9139, 124H6, Cell Signaling), anti-HIF-1 $\alpha$ (ab82832, Abcam), anti-HIF-2 $\alpha$ (ab199, Abcam), anti- $\beta$ actin (sc-47778, Santa Cruz Biotechnology). Secondary 
antibodies were obtained from Bio-Rad: IgG Goat AntiRabbit IgG (H+L)-HRP conjugate (170-6515, BioRad) and $\mathrm{IgG}$ Goat-Anti Mouse IgG $(\mathrm{H}+\mathrm{L})-\mathrm{HRP}$ conjugate (170-6516, BioRad).

\section{Protein kinase activity assay}

Protein kinase CK2 activity was determined in cell extracts using either the $\mathrm{CK} 2$ specific peptide (CK2-tide: RRRADDSDDDDD) or the eIF2 $\beta$-derived peptide (eIF2 $\beta$ tide: MSGDEMIFDPTMSKKKKKKKKP) as substrates, in the presence of phosphorylation mixture as described previously [30]. The activity exhibited by the catalytic subunits (CK2 $\left.\alpha / \alpha^{\prime}\right)$ alone was also determined by ingel activity assays. Cell lysates were run on an $11 \%$ polyacrylamide gel electrophoresis containing $\beta$-casein $(0.5 \mathrm{mg} / \mathrm{ml})$ in the running and the stacking gel. After protein separation, proteins on the gel were renatured and then the gel were incubated with the phosphorylation medium containing $1 \mathrm{mM}\left[\gamma^{33} \mathrm{P}\right]$ ATP [52]. The gel was stained with Comassie, dried and analyzed by autoradiography (CyclonePlus Storage Phosphor System, PerkinElmer).

\section{Statistical analysis}

Statistical Analysis was performed using GraphPad Prism 5 program for Windows. One-way ANOVA with a Tukey's post-hoc test was used to analyze the relationships between CK $2 \alpha$ and CK2 $\beta$ expression levels in TMAs. Associations between pSTAT3 S727 and CK2 $\beta$ expression and clinicopathologic parameters were evaluated with the nonparametric Mann-Whitney $U$ test. Disease-free survival was calculated as the date of surgery to the date of loco-regional or distant recurrence. Subsequently, KaplanMeier survival estimates were compared using the logrank test. Multivariate analysis was performed using a Cox regression model to estimate the independent prognostic importance of clinicopathologic parameters. Statistical analysis was performed with the Statistical Package for Social Sciences, version 12 software (SPSS).

Student's $t$-test was used to analyze CK2 subunits expression in ccRCC tumor samples by WB analyses as well as the cell growth and the expression and phosphorylation of the different proteins in the CK2silenced cell. Statistical significance was set at $\left(^{*}\right) p<$ $0.05,\left({ }^{* *}\right) p<0.01,\left({ }^{* * *}\right) p<0.001$, and $\left.{ }^{* * * *}\right) p<0.0001$.

\section{ACKNOWLEDGMENTS AND FUNDING}

This work was supported in part by the Ministerio de Ciencia e Innovación (BFU2009-10189 to E.I. and SAF2011-29506 and SAF2014-59945-R to A.M.); Fundació La Marató de TV3 (Ref: 052410 to A.M.); REDINREN 2.0 Ref: RD12/0021/0013 (A.M.) the Fundación Senefro (SEN to A.M.), the Kure It-AACR Grant for Kidney Cancer Research to A.M. and the Associazione
Italiana per la Ricerca sul Cancro, AIRC (IG 14180 to L.A.P.). The samples used in this study were provided by the Tumor Bank of the Vall d'Hebron University Hospital Biobank with appropriate ethical approval (supported by the Xarxa de Bancs de Tumors de Catalunya sponsored by Pla Director d'Oncología de Catalunya (XBTC); supported by the RETICS de Biobancos (ISCIII), Spain.

\section{CONFLICTS OF INTEREST}

The authors declare no conflicts of interest.

\section{REFERENCES}

1. Ljungberg B, Campbell SC, Cho HY, Jacqmin D, Lee JE, Weikert S, Kiemeney LA. The Epidemiology of Renal Cell Carcinoma. Eur Urol. 2011; 60:615-21. https://doi. org/10.1016/j.eururo.2011.06.049.

2. Chow WH, Dong LM, Devesa SS. Epidemiology and risk factors for kidney cancer. Nat Rev Urol. 2010; 7:245-57. https://doi.org/10.1038/nrurol.2010.46.

3. Ng CS, Wood CG, Silverman PM, Tannir NM, Tamboli P, Sandler CM. Renal cell carcinoma: diagnosis, staging, and surveillance. AJR Am J Roentgenol. 2008; 191:1220-32. https://doi.org/10.2214/AJR.07.3568.

4. Rini BI, Campbell SC, Escudier B. Renal cell carcinoma. The Lancet. 2009; 1119-32. https://doi.org/10.1016/ S0140-6736(09)60229-4.

5. Puisieux A, Brabletz T, Caramel J. Oncogenic roles of EMT-inducing transcription factors. Nat Cell Biol. 2014; 16:488-94. https://doi.org/10.1038/ncb2976.

6. O'Mahony FC, Faratian D, Varley J, Nanda J, Theodoulou M, Riddick ACP, Harrison DJ, Stewart GD. The use of automated quantitative analysis to evaluate epithelial-to-mesenchymal transition associated proteins in clear cell renal cell carcinoma. PLoS One. 2012; 7:e31557. https://doi.org/10.1371/journal.pone.0031557.

7. Gonzalez DM, Medici D. Signaling mechanisms of the epithelial-mesenchymal transition. Sci Signal. 2014; 7:re8. https://doi.org/10.1126/scisignal.2005189.

8. Shen C, Kaelin WG. The VHL/HIF axis in clear cell renal carcinoma. Semin Cancer Biol. 2013; 23:18-25. https://doi. org/10.1016/j.semcancer.2012.06.001.

9. Baldewijns MM, Van Vlodrop IJH, Vermeulen PB, Soetekouw PM, Van Engeland M, De Bruïne AP. VHL and HIF signalling in renal cell carcinogenesis. J Pathol. 2010; 221:125-38. https://doi.org/10.1002/path.2689.

10. Guo C, Yang G, Khun K, Kong X, Levy D, Lee P, Melamed J. Activation of Stat3 in renal tumors. Am J Transl Res. 2009; 1:283-90.

11. Horiguchi A, Asano T, Kuroda K, Sato A, Asakuma J, Ito K, Hayakawa M, Sumitomo M, Asano T. STAT3 inhibitor WP1066 as a novel therapeutic agent for renal cell carcinoma. Br J Cancer. 2010; 102:1592-9. https://doi. org/10.1038/sj.bjc.6605691. 
12. Pawlus MR, Wang L, Hu CJ. STAT3 and HIF1 $\alpha$ cooperatively activate HIF1 target genes in MDA-MB-231 and RCC4 cells. Oncogene. 2014; 33:1670-79. https://doi. org/10.1038/onc.2013.115.

13. Cuadros T, Trilla E, Sarro E, Vila MR, Vilardell J, De Torres I, Salcedo M, Lopez-Hellin J, Sanchez A, Cajal SRY, Itarte E, Morote J, Meseguer A. HAVCR/KIM-1 activates the IL-6/ STAT-3 pathway in clear cell renal cell carcinoma and determines tumor progression and patient outcome. Cancer Res. 2014; 74:1416-28. https://doi.org/10.1158/0008-5472. CAN-13-1671.

14. Pluemsampant S, Safronova OS, Nakahama KI, Morita I. Protein kinase CK2 is a key activator of histone deacetylase in hypoxia-associated tumors. Int $\mathrm{J}$ Cancer. 2008; 122:333-41. https://doi.org/10.1002/ijc.23094.

15. Ampofo E, Kietzmann T, Zimmer A, Jakupovic M, Montenarh M, Götz C. Phosphorylation of the von HippelLindau protein (VHL) by protein kinase CK2 reduces its protein stability and affects p53 and HIF-1 $\alpha$ mediated transcription. Int J Biochem Cell Biol. 2010; 42:1729-35. https://doi.org/10.1016/j.biocel.2010.07.008.

16. Guerra B, Rasmussen TDL, Schnitzler A, Jensen HH, Boldyreff BS, Miyata Y, Marcussen $\mathrm{N}$, Niefind $\mathrm{K}$, Issinger OG. Protein kinase CK2 inhibition is associated with the destabilization of HIF-1 $\alpha$ in human cancer cells. Cancer Lett. 2015; 356:751-61. https://doi.org/10.1016/j.canlet.2014.10.026.

17. Zheng Y, Qin H, Frank SJ, Deng L, Litchfield DW, Tefferi A, Pardanani A, Lin FT, Li J, Sha B, Benveniste EN. A CK2-dependent mechanism for activation of the JAKSTAT signaling pathway. Blood. 2011; 118:156-66. https:// doi.org/10.1182/blood-2010-01-266320.

18. Quotti Tubi L, Gurrieri C, Brancalion A, Bonaldi L, Bertorelle R, Manni S, Pavan L, Lessi F, Zambello R, Trentin L, Adami F, Ruzzene M, Pinna LA, et al. Inhibition of protein kinase CK2 with the clinical-grade small ATPcompetitive compound CX-4945 or by RNA interference unveils its role in acute myeloid leukemia cell survival, p53-dependent apoptosis and daunorubicin-induced cytotoxicity. J Hematol Oncol. 2013; 6:78. https://doi. org/10.1186/1756-8722-6-78.

19. Manni S, Brancalion A, Mandato E, Tubi LQ, Colpo A, Pizzi M, Cappellesso R, Zaffino F, Di Maggio SA, Cabrelle A, Marino F, Zambello R, Trentin L, et al. Protein Kinase CK2 Inhibition Down Modulates the NF- $\mathrm{BB}$ and STAT3 Survival Pathways, Enhances the Cellular Proteotoxic Stress and Synergistically Boosts the Cytotoxic Effect of Bortezomib on Multiple Myeloma and Mantle Cell Lymphoma Cells. PLoS One. 2013; 8:e75280. https://doi.org/10.1371/journal. pone.0075280.

20. Litchfield DW. Protein kinase CK2: structure, regulation and role in cellular decisions of life and death. Biochem J. 2003; 369:1-15. https://doi.org/10.1042/BJ20021469.
21. Bischoff $\mathrm{N}$, Olsen B, Raaf J, Bretner M, Issinger OG, Niefind K. Structure of the human protein kinase CK2 $\alpha^{\prime}$ catalytic subunit CK2 and interaction thermodynamics with the regulatory subunit CK2 $\beta$. J Mol Biol. 2011; 407:1-12. https://doi.org/10.1016/j.jmb.2011.01.020.

22. Lolli G, Pinna LA, Battistutta R. Structural determinants of protein kinase $\mathrm{CK} 2$ regulation by autoinhibitory polymerization. ACS Chem Biol. 2012; 7:1158-63. https:// doi.org/10.1021/cb300054n.

23. Lolli G, Ranchio A, Battistutta R. Active form of the protein kinase CK2 $\alpha 2 \beta 2$ Holoenzyme holoenzyme is a strong complex with symmetric architecture. ACS Chem Biol. 2014; 9:366-71. https://doi.org/10.1021/cb400771y.

24. Deshiere A, Duchemin-Pelletier E, Spreux E, Ciais D, Combes F, Vandenbrouck Y, Couté Y, Mikaelian I, Giusiano S, Charpin C, Cochet C, Filhol O. Unbalanced expression of CK2 kinase subunits is sufficient to drive epithelial-tomesenchymal transition by Snail1 induction. Oncogene. 2013; 32:1373-83. https://doi.org/10.1038/onc.2012.165.

25. Stalter G, Siemer S, Becht E, Ziegler M, Remberger K, Issinger OG. Asymmetric expression of protein kinase CK2 subunits in human kidney tumors. Biochem Biophys Res Commun. 1994; 202:141-7. https://doi.org/10.1006/ bbrc.1994.1904.

26. Roelants C, Giacosa S, Duchemin-Pelletier E, McLeerFlorin A, Tisseyre C, Aubert C, Champelovier P, Boutonnat J, Descotes JL, Rambeaud JJ, Arnoux V, Long JA, Pasquier D, et al. Dysregulated Expression of Protein Kinase CK2 in Renal Cancer. In: Ahmed K, Issinger OG, Szyszka R, editors. Protein Kinase CK2 Cellular Function in Normal and Disease States. Cham: Springer International Publishing; 2015; 241-57. https:// doi.org/10.1007/978-3-319-14544-0.

27. Rabjerg M, Guerra B, Olivan-Viguera A, Nedergaard Mikkelsen ML, Kohler R, Issinger OG, Marcussen N. Nuclear localization of the CK2alpha-subunit correlates with poor prognosis in clear cell renal cell carcinoma. Oncotarget. 2017; 8:1613-27. https://doi.org/10.18632/ oncotarget. 13693.

28. Laramas M, Pasquier D, Filhol O, Ringeisen F, Descotes JL, Cochet C. Nuclear localization of protein kinase CK2 catalytic subunit (CK2 $\alpha$ ) is associated with poor prognostic factors in human prostate cancer. Eur J Cancer. 2007; 43:928-34. https://doi.org/10.1016/j.ejca.2006.11.021.

29. Pallares J, Llobet D, Santacana M, Eritja N, Velasco A, Cuevas D, Lopez S, Palomar-Asenjo V, Yeramian A, Dolcet X, Matias-Guiu X. CK2beta is expressed in endometrial carcinoma and has a role in apoptosis resistance and cell proliferation. Am J Pathol. 2009; 174:287-96. https://doi.org/10.2353/ajpath.2009.080552.

30. Ruzzene M, Pinna LA. Addiction to protein kinase CK2: A common denominator of diverse cancer cells? Biochim Biophys Acta. 2010; 1804:499-504. https://doi.org/10.1016/j. bbapap.2009.07.018. 
31. Zhou F, Xu J, Ding G, Cao L. Overexpressions of CK2 $\beta$ and XIAP are associated with poor prognosis of patients with cholangiocarcinoma. Pathol Oncol Res. 2014; 20:73-9. https://doi.org/10.1007/s12253-013-9660-y.

32. Nitta RT, Gholamin S, Feroze AH, Agarwal M, Cheshier $\mathrm{SH}$, Mitra SS, Li G. Casein kinase $2 \alpha$ regulates glioblastoma brain tumor-initiating cell growth through the $\beta$-catenin pathway. Oncogene. 2015; 34:3688-99. https:// doi.org/10.1038/onc.2014.299.

33. Liu Y, Amin EB, Mayo MW, Chudgar NP, Bucciarelli PR, Kadota K, Adusumilli PS, Jones DR. CK2 $\alpha$ ' Drives Lung Cancer Metastasis by Targeting BRMS1 Nuclear Export and Degradation. Cancer Res. 2016; 76:2675-86. https:// doi.org/10.1158/0008-5472.CAN-15-2888.

34. Zakharchenko O, Greenwood C, Lewandowska A, Hellman U, Alldridge L, Souchelnytskyi S. Meta-data analysis as a strategy to evaluate individual and common features of proteomic changes in breast cancer. Cancer Genomics and Proteomics. 2011; 8:1-14.

35. Pizzi M, Piazza F, Agostinelli C, Fuligni F, Benvenuti P, Mandato E, Casellato A, Rugge M, Semenzato G, Pileri SA. Protein kinase CK2 is widely expressed in follicular, Burkitt and diffuse large B-cell lymphomas and propels malignant B-cell growth. Oncotarget. 2015; 6:6544-52. https://doi. org/10.18632/oncotarget.3446.

36. Golden D, Cantley LG. Casein kinase 2 prevents mesenchymal transformation by maintaining Foxc2 in the cytoplasm. Oncogene. 2015; 34:4702-12. https://doi. org/10.1038/onc.2014.395.

37. Zheng Y, McFarland BC, Drygin D, Yu H, Bellis SL, Kim H, Bredel M, Benveniste EN. Targeting protein kinase CK2 suppresses prosurvival signaling pathways and growth of glioblastoma. Clin Cancer Res. 2013; 19:6484-94. https://doi.org/10.1158/1078-0432.CCR-13-0265.

38. Borgo C, Franchin C, Scalco S, Bosello-Travain V, DonellaDeana A, Arrigoni G, Salvi M, Pinna LA. Generation and quantitative proteomics analysis of CK $2 \alpha / \alpha^{\prime}(-/-)$ cells. Sci Rep. 2017; 7:42409. https://doi.org/10.1038/srep42409.

39. Salvi M, Sarno S, Marin O, Meggio F, Itarte E, Pinna LA. Discrimination between the activity of protein kinase CK2 holoenzyme and its catalytic subunits. FEBS Lett. 2006; 580:3948-52. https://doi.org/10.1016/j.febslet.2006.06.031.

40. Di Maira G, Salvi M, Arrigoni G, Marin O, Sarno S, Brustolon F, Pinna LA, Ruzzene M. Protein kinase CK2 phosphorylates and upregulates Akt/PKB. Cell Death Differ. 2005; 12:668-77. https://doi.org/10.1038/sj.cdd.4401604.

41. Girardi C, James P, Zanin S, Pinna LA, Ruzzene M. Differential phosphorylation of Akt1 and Akt2 by protein kinase CK2 may account for isoform specific functions. Biochim Biophys Acta. 2014; 1843:1865-74. https://doi. org/10.1016/j.bbamcr.2014.04.020.

42. Filhol O, Giacosa S, Wallez Y, Cochet C. Protein kinase CK2 in breast cancer: the $\mathrm{CK} 2 \beta$ regulatory subunit takes center stage in epithelial plasticity. Cell Mol Life Sci. 2015; . https:// doi.org/10.1007/s00018-015-1929-8.

43. Mikami S, Katsube K, Oya M, Ishida M, Kosaka T, Mizuno R, Mukai M, Okada Y. Expression of Snail and Slug in renal cell carcinoma: E-cadherin repressor Snail is associated with cancer invasion and prognosis. Lab Investig. 2011; 91:1443-58. https://doi.org/10.1038/labinvest.2011.111.

44. Evans AJ, Russell RC, Roche O, Burry TN, Fish JE, Chow VW, Kim WY, Saravanan A, Maynard MA, Gervais ML, Sufan RI, Roberts AM, Wilson LA, et al. VHL promotes E2 box-dependent E-cadherin transcription by HIFmediated regulation of SIP1 and snail. Mol Cell Biol. 2007; 27:157-69. https://doi.org/10.1128/MCB.00892-06.

45. Maru S, Ishigaki Y, Shinohara N, Takata T, Tomosugi N, Nonomura K. Inhibition of mTORC2 but not mTORC1 up-regulates E-cadherin expression and inhibits cell motility by blocking HIF-2 $\alpha$ expression in human renal cell carcinoma. J Urol. 2013; 189:1921-9. https://doi. org/10.1016/j.juro.2012.11.010.

46. Mottet D, Ruys SPD, Demazy C, Raes M, Michiels C. Role for casein kinase 2 in the regulation of HIF-1 activity. Int $\mathrm{J}$ Cancer. 2005; 117:764-74. https://doi.org/10.1002/ijc.21268.

47. Jung JE, Lee H, Cho I, Chung DH, Yoon S, Yang YM, Lee JW, Choi S, Park J, Ye S, Chung M. STAT3 is a potential modulator of HIF-1-mediated VEGF expression in human renal carcinoma cells. FASEB J. 2005; 19:1296-8.

48. Rozovski U, Harris DM, Li P, Liu Z, Jain P, Veletic I, Burger J, Brien SO, Bose P, Thompson P, Jain N, Keating MJ, Estrov Z. Constitutive Phosphorylation of STAT3 by the CK2-BLNK-CD5 Complex. Mol Cancer Res. 2017.

49. Zhang HX, Jiang SS, Zhang XF, Zhou ZQ, Pan QZ, Chen CL, Zhao JJ, Tang Y, Xia JC, Weng DS. Protein kinase $\mathrm{CK} 2 \alpha$ catalytic subunit is overexpressed and serves as an unfavorable prognostic marker in primary hepatocellular carcinoma. Oncotarget. 2015; 6:34800-17. https://doi. org/10.18632/oncotarget.5470.

50. Gapany M, Faust RA, Tawfic S, Davis A, Adams GL, Ahmed K. Association of elevated protein kinase CK2 activity with aggressive behavior of squamous cell carcinoma of the head and neck. Mol Med. 1995; 1:659-66.

51. Pinna LA. Protein kinase CK2: a challenge to canons. J Cell Sci. 2002; 115:3873-8. https://doi.org/10.1242/jcs.00074.

52. Ruzzene M, Di Maira G, Tosoni K, Pinna LA. Assessment of CK2 constitutive activity in cancer cells. Methods Enzymol. 2010; 484:495-514. https://doi.org/10.1016/B978-0-12-381 298-8.00024-1.

53. Lolkema MP, Gervais ML, Snijckers CM, Hill RP, Giles RH, Voest EE, Ohh M. Tumor suppression by the von Hippel-Lindau protein requires phosphorylation of the acidic domain. J Biol Chem. 2005; 280:22205-11. https:// doi.org/10.1074/jbc.M503220200.

54. Mandal T, Bhowmik A, Chatterjee A, Chatterjee U, Chatterjee S, Ghosh MK. Reduced phosphorylation of 
Stat 3 at Ser- 727 mediated by casein kinase 2 - Protein phosphatase 2A enhances Stat3 Tyr-705 induced tumorigenic potential of glioma cells. Cell Signal. 2014; 26:1725-34. https://doi.org/10.1016/j.cellsig.2014.04.003.

55. Raman C, Kuo A, Deshane J, Litchfield DW, Kimberly RP. Regulation of casein kinase 2 by direct interaction with cell surface receptor CD5. JBC. 1998; 273:19183-9.

56. Cuadros T, Trilla E, Vilà MR, de Torres I, Vilardell J, Messaoud NB, Salcedo M, Sarró E, López-Hellin J, Blanco A, Mir C, Ramón y Cajal S, Itarte E, et al. Hepatitis A virus cellular receptor $1 /$ kidney injury molecule- 1 is a susceptibility gene for clear cell renal cell carcinoma and hepatitis A virus cellular receptor/kidney injury molecule-1 ectodomain shedding a predictive biomarker of tumour progression. Eur J Cancer. 2013; 49:2034-47. https://doi. org/10.1016/j.ejca.2012.12.020.

57. Llorens F, Roher N, Miró FA, Sarno S, Ruiz FX, Meggio F, Plana M, Pinna LA, Itarte E. Eukaryotic translationinitiation factor eIF2beta binds to protein kinase CK2: effects on CK2alpha activity. Biochem J. 2003; 375:623-31. https://doi.org/10.1042/BJ20030915. 